\title{
Ortaokul Matematik Öğretmen Adaylarının Cebir Öğrenme Alanına İlişkin Alan ve Pedagojik Alan Bilgilerinin İncelenmesi
}

\section{Investigation of Elementary School Mathematics Teacher Candidates' Subject Matter Knowledge and Pedagogical Content Knowledge Regarding the Algebra Learning Field}

\author{
Feriha Hande IDIL ${ }^{l,}$, Serkan NARLI ${ }^{2}$
}

\author{
1Sorumlu Yazar, Dr., Milli Eğitim Bakanlı̆̆l, Türkiye, deuhande@gmail.com, \\ (https://orcid.org/0000-0002-6205-7278) \\ ${ }^{2}$ Prof. Dr., Matematik ve Fen Bilimleri Eğitimi Bölümü, Buca Eğitim Fakültesi, Dokuz Eylül \\ Üniversitesi, Türkiye, serkan.narli@deu.edu.tr,(https://orcid.org/0000-0001-8629-8722)
}

Geliş Tarihi: 29.03.2021

Kabul Tarihi: 09.11.2021

\section{ÖZ}

$\mathrm{Bu}$ araştırmanın amacı, ortaokul matematik öğretmen adaylarının 8. sınıf cebir öğrenme alanına ilişkin alan ve pedagojik alan bilgilerini, "Öğretmek İçin Matematik Bilgisi” (ÖMB) modelinden yararlanarak incelemektir. ÖMB modeli, öğretmenlerin matematik öğretimi için sahip olmaları gereken bilgileri ortaya koymaktadır. Söz konusu modelin matematik öğretiminde yol gösterici olarak kullanılabileceği ve dolayısıyla öğretmen yetiştirme sürecine katkı sağlayabileceği düşünülmektedir. Araştırma nitel araştırma yöntemlerinden biri olan özel durum çalışması deseninden yararlanılarak yürütülmüştür. Araştırmanın katılımcılarını, Türkiye'de bir devlet üniversitesinde öğrenim gören üç son sınıf ortaokul matematik öğretmen adayı oluşturmaktadır. Çalışmada yer alan öğretmen adayları ölçüt örnekleme yöntemiyle belirlenmiştir. Her bir öğretmen adayı ile ÖMB modelinin bileşenlerine ilişkin görüşmeler yapılmıştır. Öğretmen adaylarının öğretim süreçleri gözlenmiş ve video kamera ile kaydedilmiştir. Öğretim süreçlerinin tamamlanmasının ardından öğretmen adayları ile genel bir görüşme daha yapılmıştır. Araştırmanın sonuçları, öğretmen adaylarının cebir öğrenme alanına ilişkin alan ve pedagojik alan bilgilerinde eksiklikler olduğunu göstermiştir. Öğretmen adaylarının eksikliklerinin özellikle uzmanlık alan bilgisi bileşenlerinde yoğunlaştığ 1 tespit edilmiştir.

Anahtar Kelimeler: Öğretmek için matematik bilgisi, alan bilgisi, pedagojik alan bilgisi, cebir öğrenme alanı, ortaokul matematik ögretmen adayları.

\begin{abstract}
The purpose of this study is to examine the elementary school mathematics teacher candidates' subject matter knowledge and pedagogical content knowledge regarding the 8th grade algebra learning field by using "Mathematical Knowledge for Teaching (MKT)" model which developed by Ball, Thames and Phelps (2008). MKT model reveals the knowledge that teachers should have for teaching mathematics. It is thought that this model can be used as a guide in mathematics teaching and thus contribute to the teacher training process. The research was conducted by using the case study design, which is one of the qualitative research methods. The participants of the study were three middle school mathematics teacher candidates who were in their last year of the education process in a state university in Turkey. The teacher candidates who took part in the study were determined by criterion sampling method. First of all, interviews were made with each teacher candidate regarding the components of the MKT model. Then, the teaching processes of the teacher candidates were observed and recorded with a video camera. After
\end{abstract}


the teaching processes were completed, another general interview was held with the teacher candidates. The study results indicated that there are deficiencies in subject matter knowledge and pedagogical content knowledge of the teacher candidates regarding the algebra learning field. It was determined that the shortcomings of the teacher candidates were mainly in the specialized content knowledge components.

Keywords: Mathematical knowledge for teaching, subject matter knowledge, pedagogical content knowledge, algebra learning area, middle school mathematics teacher candidates.

\section{GíRiş}

Amerika Birleşik Devletleri Ulusal Matematik Öğretmenleri Konseyi (National Council of Teachers of Mathematics [NCTM], 2000) yayınladığı matematik ölçütlerinde öğrencilerin, kendilerini çevreleyen dünyadaki problemleri çözmede matematikten yararlanmaları gerektiğini belirtmektedir. Söz konusu ölçütlere göre, matematiksel bilgi bireyin çevresini anlamlandırabilmesi için oldukça önemlidir. Günlük yaşamda ve iş hayatında gerekli olan analiz yapabilme, iletişim kurabilme ve yaratıcı düşünebilme gibi üst düzey davranışların gelişimini sağlayan bir alan olarak matematiğin öğrenilmesi kaçınılmazdır. Matematiğin böylesine önemli olması matematik öğretimi üzerine yapılan araştırmalara hız kazandırmıştır. Söz konusu güncel çalışmalar neticesinde, geleneksel yaklaşımdan ileri gelen "Ne öğretelim?" sorusundan "Nasıl öğretelim?" sorusuna doğru bir geçiş yaşanmıştır (Çelik ve diğerleri, 2018).

Shulman'ın öğretmen bilgisinin ayrıntılandırılması hakkında yapmıș oldukları çalışmalar eğitim çevrelerinde büyük bir heyecan yaratmıştır. Öğretmen alan bilgisinin önemli bir parçası olarak gösterdiği ve "Pedagojik Alan Bilgisi" olarak isimlendirdiği bu kavram 1980'lerin ortalarında literatürde yerini almıştır. Bu kavramla beraber alan bilgisi ile pedagojik alan bilgisinin farklı kavramlar olduklarını kuramsal olarak ilk defa açıklayan Shulman olmuştur (Akar, 2010). Pedagojik alan bilgisi, bir öğretmeni bir bilim adamından ayıran bilgi tipidir. Konunun “öğretilebilirliğini” ele alır (Shulman, 1986). Shulman'ın fikirleri eğitim camiasına önemli bir sonuç sunmuş ve onları bu konu üzerine düşünmeye itmiştir. Çünkü o güne kadar eğitim camiası bir konuda hemfikirdi: Bir öğretmenin alan bilgisi düzeyi ne kadar yüksekse o derecede iyi bir ögretmen olur ve öğrencilerinin ders başarısı da buna ilintili olarak artar (Wilson, Floden ve Ferrini Mundy, 2001'den akt., Akar, 2010). Matematik öğretmenlerini, mühendisler, doktorlar veya fizikçiler gibi matematiği iyi bilen yetişkinlerden ayıran nokta matematik alanının nasıl anlamlı bir şekilde öğretilebileceği bilgisidir (Shulman, 1986, 1987). Shulman, bu açıklamasıyla matematik öğretmenlerini matematiği iyi yapabilen meslek gruplarından ayırarak alanında etkili bir öğretmen olabilmek için öğretmenin öğretime özgü bilgisinin (pedagojik alan bilgisi) oldukça önemli olduğunu belirtmiştir.

Shulman'ın çalışmalarıyla beraber öğretmenin rolü, bir müfredat uygulayıcısı olmaktan öğrenme ortamının organizatörü ve öğrenci öğrenmesinin yapı kurucusu olmaya doğru kayma göstermiştir (Even ve Tirosh, 1995). Öğretmen bilgi yapısı üzerindeki bu değişimlerin birçok araştırmacıyı etkilediği görülmüştür. Bu doğrultuda Shulman'ın alan bilgisi sınıflandırmasının öğretmen bilgisi üzerine etkilerini inceleyen çeşitli araştırmalar yapılmıştır (Ball, 1990; Borko ve diğerleri, 1992; Goulding, Rowland ve Barber, 2002). Ayrica Shulman'ın öğretmen bilgisi kategorisi üzerine kurulu yeni kuramsal çerçeveler oluşturan araştırmalar da vardır (Gess Newsome, 1999; Hill ve Ball, 2004; Kolis ve Dunlap, 2004).

Shulman'ın düşüncelerinin eğitim camiası tarafından yoğun bir şekilde ilgi görmesi öğretime özel alan bilgisinin, daha açık bir ifadeyle alana ilişkin profesyonel bilginin var olmasından kaynaklanmaktadır. Ancak bu doğrultuda gerçekleştirilen araştırmaların önemli bir kısmı pedagojik alan bilgisi terimini -herhangi bir çalışma alanını göz önüne almaksızınöğretmen bilgisi ve eğitimi hakkında genel fikirler oluşturmak amacıyla kullanmışlardır. Eisenhart ve Borko (1993), öğretmenin alan bilgisinin öğretmene özel olarak oluşturulması gerektiğini belirtmişlerdir. Söz konusu durum öğretmenlik bilgisi hakkında çalışmalar yapan 
akademisyenleri; mühendislik, doktorluk meslekleri gibi öğretmenlik mesleğinin de kendisine has uzmanlık alanlarına sahip olduğu ve bu uzmanlık alanlarının her disiplin için farklı niteliklere sahip olması gerektiği sonucuna götürmüştür (Shulman, 1986; Ball, Hill ve Bass, 2005; Ball, Lubienski ve Newborn, 2001).

Ball ve diğerleri matematik öğretiminde ihtiyaç duyulan özel bilgiyi araştırmak amacıyla Öğretmek için Matematik Bilgisi (ÖMB) kuramsal çerçevesini oluşturmuşlardır. Bu çalışmada, ortaokul matematik öğretmen adaylarının 8. sınıf cebir öğrenme alanına ilişkin alan ve pedagojik alan bilgilerinin söz konusu ÖMB kuramsal çerçevesi yardımıyla incelenmesi amaçlanmıştır. Cebir öğrenme alanı içinde bulunan Örüntüler ve İlişkiler, Cebirsel İfadeler ve Denklemler alt öğrenme alanlarına yer verilmiştir.

Cebir öğrenme alanının matematik dersi öğretim programlarında oldukça geniş bir yer tutan matematiğin en önemli konu alanlarından biri olması birçok matematik eğitimcisini bu alanda çalışmaya yönlendirmiştir (Baş, Çetinkaya ve Erbaş, 2011; Işık ve Çağdaşer, 2009; Olkun ve Yeşildere, 2007; Warren ve Cooper, 2008). Mantıksal çıkarım ve genelleme yapma gibi üst düzey beceriler cebire ait kazanımlar aracılı̆̆ıyla geliştirilebilir. Cebirin öğrenciler için bu denli önemli oluşu öğretimini de aynı oranda değerli kılmaktadır. Dolayısıyla, öğretmenlerin öğrencilerin başarılarını arttırmak için rehberlik etmeleri ve çabalarını doğru bir şekilde yönlendirmeleri önem kazanmaktadır (Işık ve Çelik, 2017). Öğrenme sürecinde öğrencilerin cebire ilişkin sahip oldukları kavram yanılgılarını ve sık yaptıkları hataları belirlemek ve bunları gidermek öğretmenin görevlerindendir (Ersoy ve Ardahan, 2003). Bu doğrultuda söz konusu çalışma aracılığıyla, öğretmen adaylarının cebir öğrenme alanına dair sahip oldukları alan bilgilerinin yanı sıra öğretime yönelik bilgilerinin de ortaya konulması amaçlanmıştır. Literatürde yer alan birçok araştırmanın aksine, çalışmanın öğretmen adayları üzerinden gözlem, görüşme ve doküman analizi gibi nitel veri toplama yöntemlerinden faydalanılarak gerçekleştirilmesi planlanmıştır.

\section{1. Çalışmanın Kuramsal Çerçevesi}

Çalışmada öğretmen adaylarının söz konusu yeterlilik alanları derinlemesine incelenmek istendiğinden ÖMB kuramsal çerçevesinden yararlanılmıştır. Çünkü Eisenhart ve Borko'ya (1993) göre bir öğretmenin öğretim sürecine ilişkin gözlem verilerinin analizinde, çoğunlukla sergilenen davranışların ya da alınan kararların hangi bilgi türünden (alan bilgisi, pedagojik alan bilgisi ya da ikisinin karışımı) etkilenildiğinin belirlenmesi oldukça zordur. Bu doğrultuda çalışmada kullanılacak olan kuramsal çerçevenin, öğretmenlerin alan ve pedagojik alan bilgilerinin hangi göstergelerle incelenmesi gerektiğini kolaylaştırması yönünde katk1 sağlayacağ d düşünülmektedir.

ÖMB kuramsal çerçevesi "Alan Bilgisi” ve "Pedagojik Alan Bilgisi” olmak üzere iki temel kategoriden oluşmaktadır. Alan Bilgisi boyutu; "Genel Alan Bilgisi" (GAB), "Uzmanlık Alan Bilgisi" (UAB), ve "Yaygın Alan Bilgisi" bileşenlerinden oluşurken; Pedagojik Alan Bilgisi boyutu; "Alan ve Öğrenci Bilgisi" (AÖB), "Alan ve Öğretme Bilgisi” (AÖtB) ve "Alan ve Müfredat Bilgisi" bileşenlerinden oluşmaktadır (Ball ve diğerleri, 2008). ÖMB kuramsal çerçevesinin bileşenleri Şekil 1'de gösterilmiştir. 


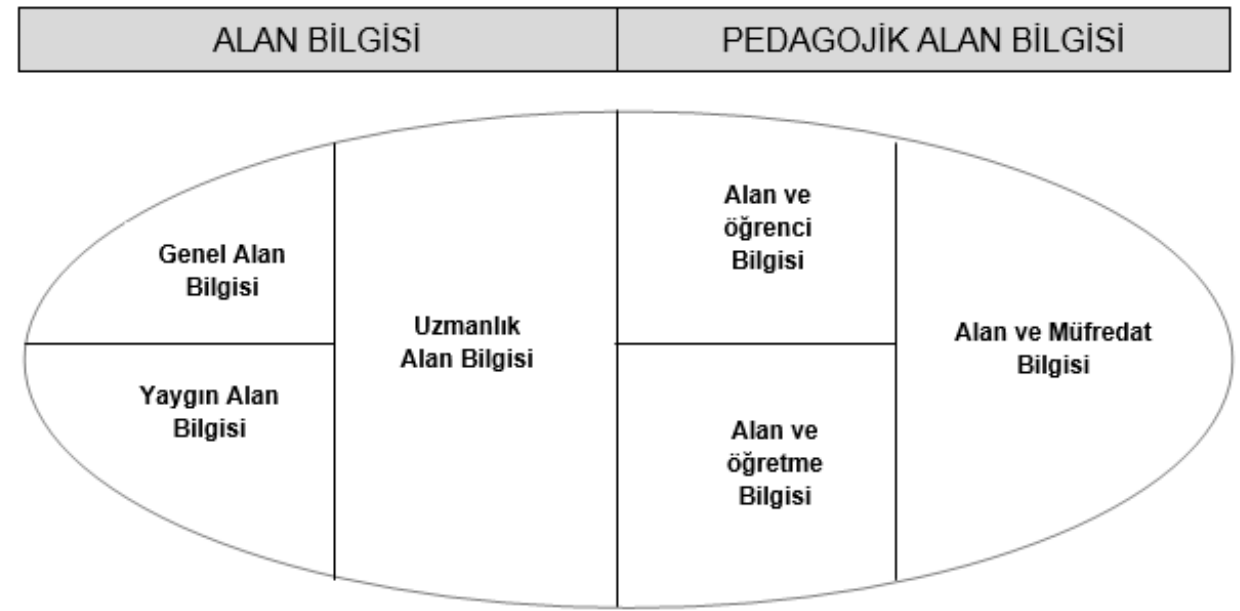

Şekil 1. Öğretmek İçin Matematik Bilgisi Modeli (Ball, Thames ve Phelps, 2008)

Bu çalışmada aşağıda özetlenen ÖMB bileşenlerine odaklanılmıştır:

Genel Alan Bilgisi: Herhangi bir matematiksel problemin doğru olarak çözülebilmesi için gerekli olan matematiksel bilgidir. Bir öğretmenin matematik konularına hâkim olması, öğrencilerin yanlış cevaplarını fark etmesi ve doğru olmayan tanımları seçebilmesi genel alan bilgisi başlığ 1 altında incelenmektedir.

Uzmanlık Alan Bilgisi: Matematik öğretimi için gerekli olan bilgi ve becerileri ifade eder. Bir matematik öğretmeninin, matematik bilen herhangi bir kişiden farklı olarak öğretime yönelik sahip olması gereken matematiksel bilgiyi içerir.

Alan ve Öğrenci Bilgisi: Öğrenciler ve matematik hakkındaki bilgiyi bir araya getiren bileşendir. Öğrencilerin kavram yanılgılarını, en sık yaptıkları hataları, neyi kolay ya da zor bulacaklarını ve neyin onları motive edeceğini bilmeyi içerir.

Alan ve Öğretme Bilgisi: Matematiksel bir konunun öğretimi için en uygun öğretim yöntemlerine karar vermek, yöntemin avantaj ve dezavantajlarına hâkim olmak, konuya uygun örnekleri seçebilmek gibi becerileri içeren bilgi birimidir.

ÖMB modeli kullanılarak gerçekleştirilen çalışmanın 8. sınıf cebir öğrenme alanına ilişkin kazanımlara ulaşmada matematik öğretmen adaylarına rehber olabileceği düşünülmektedir. ÖMB yardımıyla bir yandan öğretmen adaylarının alan ve pedagojik alan bilgileri hakkında bilgi edinimi sağlanırken bir yandan da onların cebir kazanımlarına yönelik bilgi yapıları ve olası eksikleri değerlendirilmiştir. Araştırmanın problem ve alt problemleri de buna göre belirlenmiştir. Araştırmanın problem cümlesi şu şekildedir:

ÖMB kuramsal çerçevesiyle incelendiğinde ortaokul matematik öğretmen adaylarının 8.sınıf cebir öğrenme alanına ilişkin alan ve pedagojik alan bilgileri nasıldır?

Araştırmanın alt problemleri ise şöyledir:

ÖMB modelinin

1. Genel Alan Bilgisi (GAB) bileşeni açısından,

2. Uzmanlık Alan Bilgisi (UAB) bileşeni açısından,

3. Alan ve Öğrenci Bilgisi (AÖB) bileşeni açısından,

4. Alan ve Öğretme Bilgisi (AÖtB) bileşeni açısından

ortaokul matematik öğretmen adaylarının 8. sınıf cebir öğrenme alanına ilişkin bilgileri nasıldır? 


\section{YÖNTEM}

\subsection{Araştırma Modeli}

Araştırma nitel araştırma yöntemi kullanılarak yürütülmüştür. Nitel araştırmalarda sorulacak sorular ve gözlem yapılacak durumlar çalışmanın kuramsal çerçevesine bağlıdır (Merriam, 2013). Bu araştırmada, ortaokul matematik öğretmen adaylarının cebir öğretme bilgileri, ÖMB kuramsal çerçevesi kapsamında incelenmiştir. Dolayısıyla öğretmen adaylarının durumları ayrıntılı olarak değerlendirilmek istenmiş ve öğretmen adayları ile görüşmelerin gerçekleştirilmesine ve ders anlatımlarının gözlemlenerek incelenmesine karar verilmiştir. Buna göre, araştırma özel durum çalışması deseninden yararlanılarak yürütülmüştür.

\section{2. Çalışma Grubu}

Çalışmaya başlamadan önce, İzmir Dokuz Eylül Üniversitesi Eğitim Bilimleri Enstütüsü Müdürlüğü Etik Kurulu'ndan uygunluk onayı alınmıştır (Tarih: 17/11/2014, Toplantı sayısı: 13, Karar numarası: 8). Araştırmanın katılımcılarını ilköğretim matematik öğretmenliği anabilim dalında öğrenim gören son sınıf öğrencileri oluşturmaktadır. Katılımcılar, amaçlı örnekleme yöntemlerinden ölçüt örnekleme ile seçilmiştir. Amaçlı örnekleme modellerinde temel amaç, araştırmanın konusunu oluşturan kişi, olay ya da durum hakkında ve belirli bir amaç doğrultusunda derinlemesine bilgi toplamaktır (Maxwell, 1996). Ölçüt örnekleme ise önceden belirlenmiş bütün koşulları taşıyan bireylerle çalışmayı amaç edinir. Katılımcı öğretmen adaylarının seçiminde kullanılacak ölçütler lisans ortalamaları, mesleki deneyimleri ve araştırmaya katılmaya gönüllü olmaları olmuştur. Öğretmen adaylarının hem söz konusu ölçütlere ilişkin bilgilerinin edinilmesinde hem de genel olarak matematik öğrenme ve öğretme süreci ile ilgili düşüncelerinin tespitinde araştırmacılar tarafından hazırlanan "Öğretmen Adaylarını Tanıma Formu" kullanılmıştır. Toplam 50 öğretmen adayının formda yer alan sorulara verdikleri cevaplar incelendikten sonra çalışmaya dahil edilen üç öğretmen adayı belirlenmiştir.

Seçilen öğretmen adayları özel ders vermeleri nedeniyle öğretmenlik deneyimi yaşadıklarını belirtmiştir. Ayrıca, bir öğretmen adayı lisans öğrenimi boyunca gönüllü olarak bir yardım kuruluşunda ortaokul öğrencilerine ders anlattığını ifade etmiştir. Çalışmada öğretmen adaylarının isimleri için takma isimler kullanılmıştır. Araştırmaya katılan ortaokul matematik ögretmen adaylarının cinsiyetlerine ve lisans ortalamalarına ait bilgiler Tablo 1'de verilmiştir.

Tablo 1. Öğretmen Adaylarına İlişkin Bilgiler

\begin{tabular}{lll}
\hline Öğretmen Adayı & Cinsiyet & Lisans Ortalaması \\
\hline İpek & Kadın & 2,65 \\
Nisa & Kadın & 3,01 \\
Mete & Erkek & 3,28 \\
\hline
\end{tabular}

Katılımcı öğretmen adaylarının profillerine ilişkin bilgiler ve sınıf içi düzenlemeleri aşağıda kısaca özetlenmiştir. Söz konusu bilgilerin edinilmesinde "Öğretmen Adaylarını Tanıma Formu" göz önünde bulundurularak gerçekleştirilen ön görüşme verilerinden yararlanılmıştır.

\subsection{1. Öğretmen Adayı Mete}

Mete, ilköğretim matematik öğretmenliği son sinıfta öğrenim görmektedir. Lise öğrenimini bir Anadolu öğretmen lisesinde tamamladığını ve iki yıldır özel ders vererek matematik öğretiminde deneyim kazandığını belirtmiştir. Özel ders öğrencilerinin büyük bir kısmını ortaokul 7. ve 8. sınıf öğrencilerinin oluşturduğunu ancak lise düzeyinde de öğrencilerinin olduğunu ifade etmiştir. Matematik öğretmeni olmak istemesine neden olarak öğrenim sürecinde yaşadıklarını göstermiştir. Öğrenim süreci boyunca matematik 
öğretmenlerini çok sevdiğini ve onları örnek aldığını belirtmiştir. Ayrıca, şu anki ders anlatımında dahi geçmiş yıllardaki matematik öğretmenlerinden etkilenmiş olabileceğini dile getirmiştir.

\subsubsection{Mete'nin Öğrenme Ortamının Özellikleri}

Mete, 8. sınıf cebir öğrenme alanı konularının öğretimine ilişkin derslerini 24 kişilik bir sınıfta gerçekleştirdi. Sıralar en çok aşina olunan arka arkaya oturma düzeni şeklinde düzenlendi. Mete öğrenme süreci boyunca sınıf-sıra düzeninde sadece bir kez değişikliğe gitti. Gerçekleştirdiği etkinlik sırasında, öğrencilerin birbirlerinden öğrenmelerine olanak sağlayan ve aralarındaki iletişimi arttıran küme yerleşim düzenini kullandı. İlk dersinde, hazırlamış olduğu ders notlarını projeksiyon cihazı vasıtasıyla öğrencilere sundu. Bu süreçte ara ara sınıf tahtasını da kulland1.

\subsection{2. Öğretmen Adayı İpek}

İlköğretim matematik öğretmenliği son sinıfta öğrenim gören öğretmen adayı İpek, lise öğrenimini bir düz lisede tamamlamıştır. Lisans öğreniminin ilk yılından itibaren bir yardım kuruluşunda gönüllü öğretmenlik yapmaktadır. Söz konusu kurumda ara ara görev almasının kendisine oldukça tecrübe kazandırdığını ve mesleki anlamda özgüvenini arttırdığını ifade etmiştir. İpek, söz konusu yardım kurumunda sınavlara hazırlanan ortaokul ve lise öğrenci gruplarıyla çalıştığını belirtmiştir. Ayrıca lise düzeyinde iki özel ders öğrencisi olduğunu dile getirmiştir. İlkokul ve ortaokul yıllarında matematik dersini sevmediğini ve bu alanda iyi olmadığını ifade eden İpek, bu duruma neden olarak öğretmenleri hakkındaki olumsuz düşüncelerini öne sürmüştür.

\subsubsection{1. İpek'in Öğrenme Ortamının Özellikleri}

İpek derslerini 30 kişilik klasik sınıf ortamında gerçekleştirdi. Ders süreçlerinde sıra düzeninde herhangi bir değişiklik yapmadı. İpek, 1. ve 3. derslerinde sinıfta bulunan projeksiyon cihazından yararlanarak derslerini işledi. Sunumlarında konuya ilişkin görsellerden ve video kayıtlarından sık sık faydalandı. Bu sırada ara ara sınıf tahtasını da kullandı. Konu anlatımından sonra 2. ve 4. derslerinde ise sadece tahtayı kullanarak soru çözümüne zaman ayırd1.

\subsection{3. Öğretmen Adayı Nisa}

Lise öğrenimini bir Anadolu lisesinde tamamlayan Nisa, ilköğretim matematik öğretmenliği son sınıfta öğrenim görmektedir. Lisans öğrenimi boyunca ortaokul ve lise düzeyinde öğrencilere özel ders vererek tecrübe kazandığını belirtmiştir. Özel ders öğrencilerinin çoğunluğunu ortaokul öğrencilerin oluşturduğunu ve özellikle de 8 . sinıf öğrencilerinin sayıca fazla olduğunu ifade etmiştir. Nisa her ne kadar matematik dersini sevse de lise döneminde matematik öğretmeni olmak gibi özel bir amacının olmadığını ve üniversite sınavında aldığı puana göre tercih yaptığını söylemiştir. $O$ dönemde matematik öğretmeni olmak gibi bir hedefi olmasa da lisans öğreniminin ilk yıllarında kendisine uygun bir tercih yaptığını fark ettiğini belirtmiştir.

\subsubsection{Nisa'nın Öğrenme Ortamının Özellikleri}

Nisa derslerini 32 kişilik klasik sınıf ortamında gerçekleştirdi. Öğretim süreci boyunca Nisa sınıfın sıra düzeninde herhangi bir değişiklik yapmadı. Her dört dersinde de sınıfta yer alan projeksiyon cihazını aktif olarak kullandı. Derslerini genellikle hazırladığ sürdürdü. Bu süreçte sınıf tahtasını da sık sik kullandığı gözlendi.

\subsection{Veri Toplama Araçları}

Öğretmen adaylarıyla gerçekleştirilen görüşmeler, derslere ilişkin video kayıtlar, araştırmacının gözlem sürecinde elde ettiği notlar ve öğretmen adaylarına ilişkin çeşitli dokümanlar çalışmanın veri kaynağını oluşturmaktadır. Buna göre, "Öğretmen Adaylarını 
Tanıma Formu", "Bileşenlere İlişkin Görüşme Formu", "Ders Gözlem Formu" ve "Derslere Yönelik Genel Görüşme Formu" olmak üzere dört adet veri toplama aracı geliştirilmiştir. Bu formlara uzman görüşleri alındıktan sonra uygulama öncesinde pilot çalışmalar da yapılarak son hali verilmiştir. Öğretmen Adaylarını Tanıma Formu ortaokul matematik öğretmen adaylarının kişisel geçmişleri, deneyimleri ve matematik dersini öğrenme ve öğretme süreci ile ilgili olup çalışma grubunu belirlemek amacıyla kullanılmıştır. Diğer formlar ise aşağıda tanıtılmıştır.

\subsubsection{Bileşenlere İlişskin Görüşme Formunun Geliştirilmesi}

Öğretmen adaylarıyla geçekleştirilen görüşmelerin birincisi, ders anlatımlarının gözlemlenmesinden bir hafta önce yapılmıştır. Söz konusu ön görüşmede araştırmacılar tarafından oluşturulan Bileşenlere İlişkin Görüşme Formu kullanılmıştır (Bkz. Ek 1). Söz konusu görüşmenin amacı, ÖMB teorik çerçevesinin bileşenleri doğrultusunda öğretmen adaylarının cebir öğrenme alanına ilişkin bilgilerini incelemektir.

Form, modelin 4 bileşenine ilişkin toplam 14 sorudan oluşmaktadır. Görüşme sorularının hazırlanmasında; Ball ve diğerleri (2008) tarafindan yazılan "Content Knowledge for Teaching - What makes it special?" adlı makaleden yararlanılmıştır. Form 4 bölümden oluşmaktadır. Birinci bölümde "Genel Alan Bilgisi” bileşenine ait 3 soru, ikinci bölümde "Uzmanlık Alan Bilgisi” bileşenine ait 5 soru, üçüncü bölümde "Alan ve Öğrenci Bilgisi” bileşenine ait 3 soru ve dördüncü bölümde "Alan ve Öğretme Bilgisi” bileşenine ait 3 soru yer almaktadır.

Görüşme formunda yer alan sorularla ilgili matematik eğitimi alanında çalışmalar yürüten 2 öğretim üyesinden uzman görüşü alınmıştır. Uzman görüşleri doğrultusunda gerekli ekleme ve çıarmalar yapılarak forma son hali verilmiştir. Bileşenlere ilişkin görüşme formunun 'Uzmanlık Alan Bilgisi' başlığı altında yer alan 1 soru uzman görüşleri doğrultusunda çıkartılmıştır. Ayrıca formun dil geçerlilik çalışması yapılarak forma son hali verilmiştir.

\subsubsection{Ders Gözlem Formunun Geliştirilmesi}

Araştırmacılar tarafından hazırlanan Ders Gözlem Formunun amacı öğretmen adaylarının derslerinde cebir öğrenme alanına ilişkin konuları nasıl işlediklerini ÖMB kuramsal çerçevesi kapsamında incelemektir (Bkz. Ek 2). Form yardımıyla öğretmen adaylarının derslerinde görülen bazı önemli noktalar not edilmiştir. Araştırmacı tarafından not edilen söz konusu durumlar derslerin tamamlanmasının ardından gerçekleştirilen görüşmede öğretmen adaylarına soru olarak yöneltilmiştir. Formun oluşturulmasında, Deborah Ball ve ekibi tarafından ortaya konulan "Öğretme İçin Matematik Bilgisi" kuramsal çerçevesi ile Ball ve diğerleri (2008) tarafindan yazılan "Content Knowledge for Teaching - What makes it special?" adlı makaleden yararlanılmıştır. Form, 4 bileşene ilişkin toplam 19 göstergeden oluşmaktadır. Dil geçerlilik çalışması ve uzman görüşleri sonrasında forma son hali verilmiştir. Gözlem formundaki boyutlar doğrultusunda sınıf içi video kayıtları ve gözlem notları analiz edilmiştir. Video çekimlerinin ayrıntılı olarak yazıya aktarımı yapılmıştır. Yazıya aktarımı yapılan kayıtların öğretmen adayları tarafından gözden geçirilmesiyle güvenirlik sağlanmaya çalışılmıştır.

\subsubsection{Derslere Yönelik Genel Görüşme Formunun Geliştirilmesi}

Bir diğer görüşme, öğretmen adaylarının ders anlatımlarının tamamlanmasının hemen ardından gerçekleştirilmiştir. Araştırmacılar tarafından oluşturulan Derslere Yönelik Genel Görüşme Formu ile öğretmen adaylarının dersleri esnasında yaşanan olaylar, bu olayların nedenleri ile öğretmen adaylarının yaşananlara ilişkin fikirleri ve dersleri hakkındaki öz eleştirileri anlaşılmaya çalışılmışıır (Bkz. Ek 3). Derslere Yönelik Genel Görüşme Formu'nun hazirlanmasinda; National Center for Research on Teacher Learning (NCRTL) tarafindan yayınlanan "A Study Package for Examining and Tracking Changes in Teachers' Knowledge" adlı çalışmadan yararlanılmıştır (Kennedy, 1993). Bu formda da dil geçerlik çalışması yapılmış ve 2 öğretim üyesinden uzman görüşü alınmıştır. Formda yer alan 3 soru uzman görüşleri doğrultusunda çıkartılmış ve forma son hali verilmiştir. 


\subsection{Gözlem ve Görüșme Süreci}

Belirlenen üç öğretmen adayı çalışmanın yapılış amacı ve uygulama süreci ile ilgili bilgilendirilmiştir. Ders anlatımları öncesi öğretmen adayları ile ayrı ayrı yapılan görüşmelerde "Bileşenlere İlişkin Görüşme Formu" (Bkz. Ek 1) yardımıyla öğretmen adaylarının ÖMB kuramsal çerçevesinin bileşenlerine göre cebir öğrenme alanına ilişkin sahip oldukları bilgileri incelenmiştir.

Ayrıca adaylara, araştırmacı tarafından kendi istekleri doğrultusunda ders planlarını hazırlayabilecekleri belirtilmiştir. Öğretmen adayları ortaokul matematik dersi öğretim programında yer alan 8. sınıf cebir öğrenme alanı kazanımlarına göre öğretim süreçlerinde yer verecekleri etkinlikleri, çalışma yapraklarını ve yararlanacakları materyalleri belirleyip ders planlarını hazırlamışlardır. Planları dâhilinde sunumlarını 4 ders saatinde tamamlayabileceklerini belirtmişlerdir. $\mathrm{Bu}$ ders planları da yazılı dokümanlar kapsamında değerlendirilmiştir.

$\mathrm{Bu}$ aşamadan sonra ders takibi, ortaokul matematik öğretmen adaylarının öğretmenlik uygulaması dersi kapsamında gözlem ve uygulama yaptıkları okulda gerçekleştirilmiştir. Uygulama için gerekli yasal izinler alınmıştır. Sekizinci sınıf cebir öğrenme alanına ilişkin derslerin yapıldığ 1 süre boyunca öğretmen adaylarının dersleri video kamera ile kaydedilmiştir. Ayrıca, öğretmen adaylarının ders anlatımları esnasında ortaya çıkan durumlar, araştırmacılar tarafından hazırlanan gözlem çizelgesi yardımıyla da not edilmiştir.

Ders gözlemlerinin ardından öğretmen adayları ile bir görüşme daha gerçekleştirilmiştir. Söz konusu görüşmede "Derslere Yönelik Genel Görüşme Formu" (Bkz. Ek 3) kullanılarak öğretmen adaylarının öğretim süreçlerine ilişkin kendilerini nasıl değerlendirdikleri sorgulanmıştır.

\subsection{Araştırmanın Geçerlilik ve Güvenirliği}

Nitel verilerin elde edilmesinde çeşitli veri toplama tekniklerinden faydalanılmaktadır. Verilerin farklı kaynaklardan toplanmasının sebebi, araştırmacının "sistematik hata" yapma riskini azaltmaktır (Maxwell, 1996). Nitel araştırmalarda en sık kullanılan veri toplama yöntemleri görüşme, gözlem ve doküman incelemesidir (Yıldırım ve Şimşek, 2008).

Araştırmanın geçerliliğini arttırabilmek için, görüşme ve gözlem yöntemlerine ek olarak, öğretmen adaylarının kullandığı yazılı ve görsel materyaller de araştırmaya dâhil edilmiştir. Genel olarak geçerliğe yönelik, görüşme, gözlem ve doküman incelemesi yoluyla derlenen veriler birbirleriyle karşılaş̧tırılarak ve desteklenerek analiz edilmiştir. Böylelikle veri çeşitlemesi ile araştırmanın geçerliği sağlanmıştır.

Araştırmanın güvenirliğini arttırmak için bulgular doğrudan yorum katılmadan verilmiş ve katılımcılardan doğrudan alıntılar yapılmıştır. Verilerden elde edilen kodlamalar alanında uzman iki araştırmacı tarafından ayrı ayrı kodlanmış olup, sonrasında bir araya getirilerek uyum yüzdesi hesaplanmıştır. Kodlamalar arasında \%80 oranında uyum görülmüştür. Kodlamalardaki farklılıkları ortadan kaldırmak için kodlamalar tekrar gözden geçirilmiş ve bu kodlamalarla ilgili fikir birliğine ulaşılmıştır. Bunun dışında ayrıca veri analizi süreci detaylı bir şekilde açıklanmıştır.

\subsection{Verilerin Analizi}

Öğretmen adaylarıyla yapılan görüşmeler, derslerin video kayıtları ve yazılı dokümanlar çalışmanın veri kaynağını oluşturmaktadır. Çalışmanın veri toplama aşamaları sırasıyla Tablo 2'de verilmiştir. 
Tablo 2. Araştırmanın Sırasıyla Veri Toplama Aşamaları

\begin{tabular}{ll}
\hline Sıra & Veri Toplama Aşamaları \\
\hline 1. & Öğretmen adaylarını tanıma formundan elde edilen bilgiler \\
2. & Bileşenlere ilişkin görüşmelerin ses kayıtları \\
3. & $\quad$ Birinci derslerin video kayıtları \\
4. & $\quad$ İkinci derslerin video kayıtları \\
5. & $\quad$ Üçüncü derslerin video kayıtları \\
6. & $\quad$ Dördüncü derslerin video kayıtları \\
7. & Derslere ilişkin genel görüşmelerin ses kayıtları \\
\hline
\end{tabular}

Veri analizinde içerik analizinden yararlanılmıştır. Yıldırım ve Şimşek’e (2008) göre içerik analizinde, benzeyen veriler belli temalar altında birleştirilir ve okuyucunun anlayabileceği şekilde düzenlenir. Her bir veri kaynă̆ının analizi neticesinde elde edilen sonuçlar kıyaslanarak araştırma problemlerine ilişkin genel sonuçlar elde edilmeye çalışılmıştır. Veri toplama araçlarından elde edilen veriler düzenlenerek ÖMB kuramsal çerçevesinin bileşenlerine ilişkin göstergelere göre analiz edilmiştir. Bileşenleri değerlendirmede kullanılan göstergeler Tablo 3'de sunulmuş̧tur.

Tablo 3. Kuramsal Çerçeveyi Oluşturan Bileşenlere İlişkin Göstergeler

\begin{tabular}{|c|c|}
\hline Bileşenler & Bileşenlere İlişkin Göstergeler \\
\hline $\begin{array}{c}\text { A. Genel Alan } \\
\text { Bilgisi }\end{array}$ & $\begin{array}{l}\text { A1. Öğretmenler çeşitli matematiksel hesaplamaları ve problemleri doğru bir } \\
\text { şekilde cevaplayabilirler. } \\
\text { A2. Öğretmenler öğrencilerin yaptıkları hataları fark edebilirler. } \\
\text { A3. Öğretmenler, matematiksel ifadeleri ve terimleri doğru bir şekilde } \\
\text { kullanırlar. }\end{array}$ \\
\hline $\begin{array}{l}\text { B. Uzmanlık } \\
\text { Alan Bilgisi }\end{array}$ & $\begin{array}{l}\text { B1. Öğretmenler, öğrencilerin soru ve cevaplarını nedenleriyle birlikte } \\
\text { açıklayabilirler. } \\
\text { B2. Öğretmenler, matematik alan dilini doğru bir şekilde kullanabilirler. } \\
\text { B3. Öğretmenler öğrencilere ulaşılması hedeflenen kazanımlar doğrultusunda } \\
\text { sorular yöneltebilirler. } \\
\text { B4. Öğretmenler, öğrencilerinin seviyelerini göz önüne alarak öğrenim sürecinde } \\
\text { değişiklikler yapabilirler. }\end{array}$ \\
\hline $\begin{array}{c}\text { C. Alan ve } \\
\text { Öğrenci Bilgisi }\end{array}$ & $\begin{array}{l}\text { C1. Öğretmenler, öğrencilerin yaygın hatalarını ve kavram yanılgılarını göz } \\
\text { önünde bulundurarak derslerinde bunları engelleyici yaklaşımlarda } \\
\text { bulunabilirler. } \\
\text { C2. Öğretmenler, öğrencilerin dikkatini çekebilen onları motive eden çeşitli } \\
\text { örneklere, etkinliklere derslerinde yer verebilirler. } \\
\text { C3. Öğretmenler öğrencilerinin herhangi bir konunun hangi noktasında } \\
\text { zorlanacaklarının farkındadırlar. }\end{array}$ \\
\hline $\begin{array}{c}\text { D. Alan ve } \\
\text { Ö ğretme Bilgisi }\end{array}$ & $\begin{array}{l}\text { D1. Öğretmenler, dersin hedeflerine uygun plan hazırlayabilirler ve planları } \\
\text { doğrultusunda derslerini gerçekleştirebilirler. } \\
\text { D2. Öğretmenler, derslerinde uygun strateji, yöntem ve tekniklerden } \\
\text { yararlanabilirler. } \\
\text { D3. Öğretmenler, öğrencileri kazanımlara ulaştırmada etkili olabilecek ders } \\
\text { materyallerini seçebilirler ve amaca uygun bir şekilde kullanabilirler. }\end{array}$ \\
\hline
\end{tabular}




\section{BULGULAR}

Gözlem, görüşme ve döküman analizi süreçleri sonunda her bir öğretmen adayından delde edilen veriler kuramsal çerçevenin bileşenlerine ilişkin göstergeler doğrultusunda alt başliklar halinde sunulmuştur.

\subsection{Birinci Alt Probleme İlişkin Bulgular}

Tablo 4. Genel Alan Bilgisi Bileşenine İlişkin Göstergeler

\begin{tabular}{|c|l|}
\hline Bileşen & Bileşene İlişkin Göstergeler \\
\hline $\begin{array}{c}\text { Genel Alan } \\
\text { Bilgisi }\end{array}$ & $\begin{array}{l}\text { A1. Öğretmenler çeşitli matematiksel hesaplamaları ve problemleri doğru bir şekilde } \\
\text { cevaplayabilirler. } \\
\text { A2. Öğretmenler öğrencilerin yaptıkları hataları fark edebilirler. } \\
\text { A3. Öğretmenler, matematiksel ifadeleri ve terimleri doğru bir şekilde kullanırlar. }\end{array}$ \\
\hline
\end{tabular}

Görüşme sonuçlarından ve ders video kayıtlarından elde edilen bilgilere göre öğretmen adaylarının GAB'nin birinci göstergesi bağlamında çeşitli hesaplamaları ve problemleri genel itibariyle doğru cevaplayabildikleri görülmüştür. Bu gösterge bağlamında öğretmen adaylarına yöneltilen "Özdeşlik ve denklem arasındaki fark nedir?" sorusuna verilen yanıtlar aşağıdaki gibidir:

Bence özdeşlik ile denklem arasındaki fark, özdeşliklerde eşitliğin her iki tarafindaki ifadeler birbirine aynı yapıda yani ayn değere sahip olmalı. Denklemde ise herhangi bir tarafindaki bilinmeyenler diğer tarafinda bilinen bir sayıya eşitlik durumu söz konusudur... (Mete-Bileşenlere İlişkin Görüşme).

Denklemlerde bir ya da birden fazla bilinmeyen vardır. Ayrica denklemlerin dereceleri var. Birinci dereceden, ikinci dereceden olabilir mesela. Özdeşlikler denklem sistemini oluşturma aşaması olabilir mi? Öyle sanırım. Başka bir şey söyleyemiyorum, çünkü aklıma gelmedi gerçekten. Yani arasındaki fark, özdeşlikleri bir şeye eşitlemiyoruz sanki zaten onlar bir şeyin açılımı... (İpek-Bileşenlere İlişkin Görüşme).

Denklemler de bilinmeyen var mı özdeşliklerde de var ancak özdeşliklerde kare küp kuvvetlerin alımı şeklinde oluyor. Denklemlerde amaç bilinmeyeni ya da bilinmeyenleri bulmak ama özdeşliklerde açılımlardan yararlanarak sonuca gitmeye çalışıoruz... (Nisa-Bileşenlere İlişkin Görüşme).

Öğretmen adaylarının yanıtları değerlendirildiğinde özdeşlik ve denklem arasındaki farkı belirtmekte oldukça zorlandıkları görülmüştür. Mete ve Nisa soruyu uygun bir matematiksel dil kullanarak açıklayamamalarına rağmen beklenen yanıta dolaylı da olsa yakın açıklamalar yapabilmişlerdir. Öğretmen adayı İpek'in söylemleri incelendiğinde ise beklenen yanıta yakın herhangi bir açılama yapamadığ 1 görülmüştür. Bu sorunun ardından öğretmen adaylarının GAB hakkında daha detaylı fikir sahibi olmak amacıyla probleme uygun denklem kurmayı gerektiren iki soru daha yöneltilmiştir (Bkz. Ek 1 - Bileşenlere İlişkin Görüşme Formu). Ögretmen adaylarından Mete bu iki soruda zorlanmadan problemlere uygun denklemleri yazabilmiş ve doğru cevaba ulaşmıştır. İpek'in ise her iki soru üzerinde uzun süre düşündüğü ve yanıtlarından emin olamadığı görülmüştür. İpek söz konusu soruların cevabına ilişkin denklemi kurmakta zorlanmış ancak birkaç başarısız denemenin ardından doğru cevabı verebilmiştir. Öğretmen adaylarından Nisa ise, problemlere ilişkin uygun denklemleri kuramamış dolayısıyla iki soruyu da yanlış cevaplamıştır. Gerçekleştirilen görüşmelere ek olarak öğretmen adaylarının öğretim süreçlerinin incelenmesiyle de adayların GAB hakkında bazı bilgilere ulaşılmıştır. Mete ve İpek'in öğrencilerin kendilerine yönelttiği bazı soruları cevaplamakta zorluk yaşadıkları görülmüştür. 
Özel sayı örüntüleriyle ilgili açıklamalarda bulunurken bir öğrenci ve Mete arasında yaşanan diyalog Tablo 5'te sunulmuştur.

Tablo 5. Mete'nin Birinci Dersinden Bir Bölüm

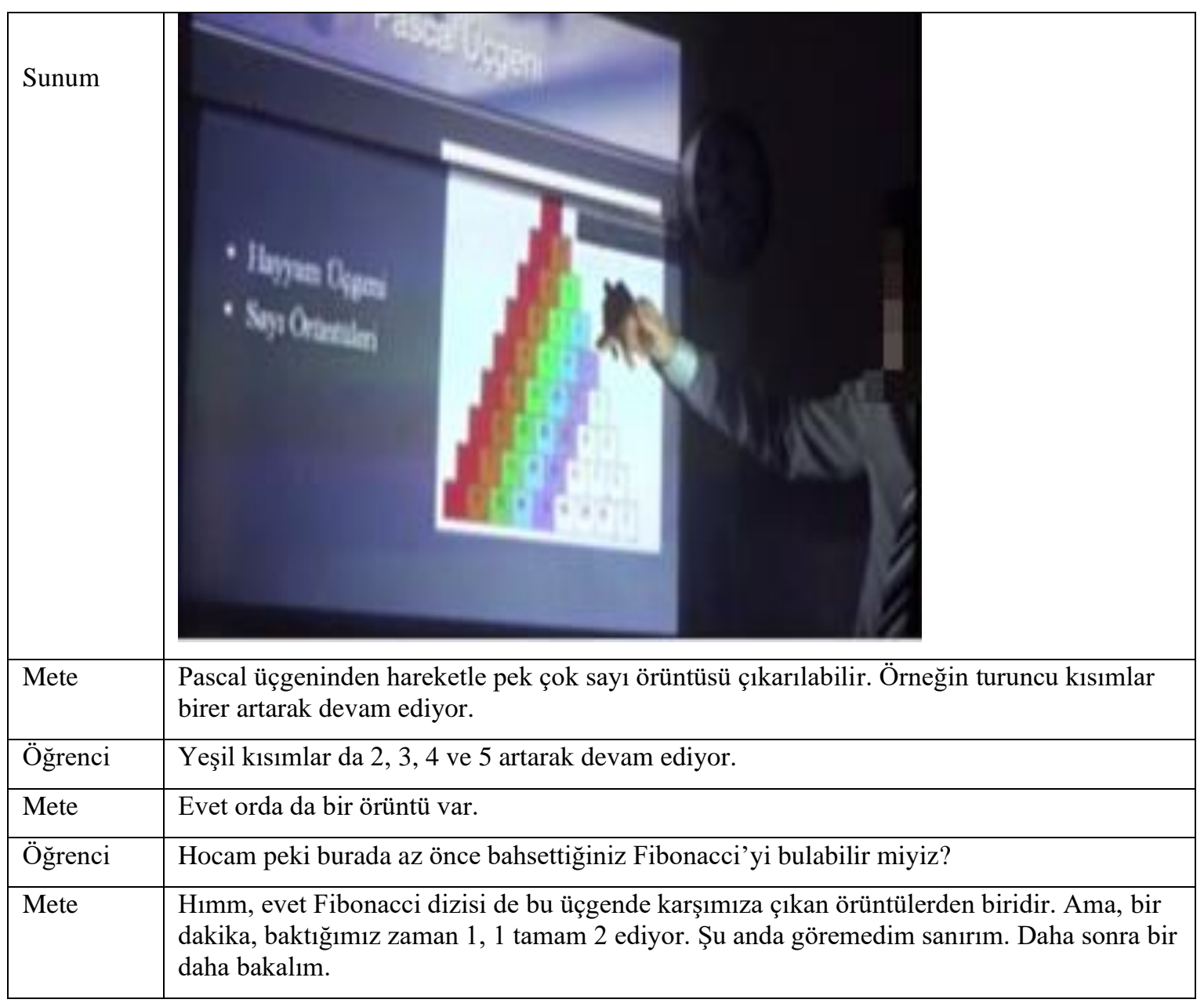

Mete, Fibonacci dizisinin de Pascal üçgeninde yer alan özel örüntülerden biri olduğunu bilmektedir. Ancak nasıl bulunacağı bilgisine sahip değildir.

Bir diğer gösterge doğrultusunda öğretmen adaylarından beklenen, öğrenci cevaplarının kontrolünü yapıp onlara doğru ya da yanlış şeklinde geri bildirim yapabilmeleridir. Üç öğretmen adayının öğretim süreçleri incelendiğinde derslerinde konuya ilişkin sorular sormaya oldukça önem verdikleri gözlenmiştir. Öğretmen adaylarından Mete ve Nisa'nın öğrenci yanıtlarını değerlendirirken İpek'e göre daha sakin davrandıkları ve bunun için daha çok zaman ayırdıkları görülmüştür. $\mathrm{Bu}$ öğretmen adayları söz isteyen her bir öğrencinin yanıtının ardından doğru ya da yanlış şeklinde geri bildirimde bulunmuşlardır. Ayrıca bazı öğrenci cevaplarının neden doğru ya da neden yanlış olduğu ile ilgili ek açıklamalar yaptılar. İşlem adımlarını takip etmeyi gerektiren bazı sorularda sıraların aralarında gezinip öğrencilerin yanıtlarını kontrol ederek de geri bildirim de bulundular.

GAB'nin üçüncü göstergesi doğrultusunda öğretmen adaylarının dersleri incelendiğinde, matematiksel ifadelerin doğru kullanımına özen gösterildiği belirlenmiştir. Ancak matematiksel ifadelerin doğru yazımı konusunda en hassas davranan öğretmen adayının Mete olduğu görülmüştür. Bunun yanı sıra, Mete öğrencileri en s1k yapılan hatalar konusunda bilgilendirmiştir. Ayrıca, öğretmen adaylarının öğretim süreçleri incelendiğinde her birinin konu için önemli olan terimlere de derslerinde yer verdikleri görülmüş̧ür. 


\section{2. İkinci Alt Probleme İlişkin Bulgular}

Tablo 6. Uzmanlık Alan Bilgisi Bileşenine İlişkin Göstergeler

\begin{tabular}{|c|l|}
\hline \multicolumn{1}{|c|}{ Bileşen } & Bileşene İlişkin Göstergeler \\
\hline $\begin{array}{c}\text { B1. Öğretmenler, öğrencilerin soru ve cevaplarını nedenleriyle birlikte } \\
\text { açılayabilirler. } \\
\text { B2. Öğretmenler, matematik alan dilini doğru bir şekilde kullanabilirler. }\end{array}$ \\
$\begin{array}{l}\text { B3.Öğretmenler öğrencilere ulaşılması hedeflenen kazanımlar doğrultusunda üretken } \\
\text { matematik soruları yöneltebilirler. } \\
\text { B4. Öğretmenler, öğrencilerinin seviyelerini göz önüne alarak öğrenim sürecinde } \\
\text { değişiklikler yapabilirler. }\end{array}$ \\
\hline
\end{tabular}

Öğretmen adaylarının dersleri, herhangi bir durumu derinlemesine öğrenmek için öğrenciler tarafından sorulan sorulara yaptıkları açıklamalar ve çeşitli öğrenci cevaplarına getirdikleri yorumlar bağlamında incelenmiş olup öğretmen adaylarından Mete ve Nisa'nın İpek'e göre söz konusu öğrenci sorularına daha fazla zaman ayırdıkları ve öğrenci cevaplarını detaylı bir şekilde ele aldıkları gözlenmiştir. Mete ve Nisa'nın yaptığı açıklamaların bir kısmı sırasıyla Tablo 7 ve Tablo 8' de gösterilmiştir.

Tablo 7. Mete'nin İkinci Dersinden Bir Bölüm

\begin{tabular}{|c|c|}
\hline Tahta & \\
\hline Mete & Bu şekilde bilinenleri bir tarafa bilinmeyenleri bir tarafa alıyoruz. \\
\hline Mete & $\begin{array}{l}\text { Evet, düzenleyelim, } 2 x+6 x \text { ve karşı taraftaki } 6 x \text { eksi olarak sol tarafa geldi. Toplarsak } 2 x \\
\text { olur. }\end{array}$ \\
\hline Öğrenci & $\begin{array}{l}\text { Hocam, eşitliğin her iki tarafından da 6x'i çıkararak da yapabilir miyiz, yani denge } \\
\text { bozulmasın? Ben öyle yaptım da. }\end{array}$ \\
\hline Mete & Öyle de doğru olur. \\
\hline Öğrenci & Ben bu şekilde anlamadım, şimdi denge bozulmadı mı? Neden eksi oldu hocam? \\
\hline Mete & $\begin{array}{l}\text { Dediğin gibi de yapabiliriz tabi ama o zaman uzun sürer. Zaten terazi üzerinde öyle } \\
\text { yapmıştık. Bu şekilde ters çevirerek yaparsan daha kısa sürüyor. Hımm, işte onun kısa yolu } \\
\text { gibi düşünebilirsin. Bir önce ki dersimizde bahsetmiştik ters çevirme metodundan. }\end{array}$ \\
\hline Mete & $\begin{array}{l}\text { Aslında burada dengeyi bozuyoruz gibi geliyor sana ama bu şekilde de dengeyi koruyoruz. } \\
\text { İşlemi iki tarafa da yazmaktansa bir tarafa yazıyoruz. Çünkü bakın burada sonuç zaten } 0 \\
\text { çıkar. Bu yüzden sadece bir tarafta işlem yapmış gibi görünüyoruz. }\end{array}$ \\
\hline
\end{tabular}

Metenin dersinde, ters çevirme metodunda odak noktası dengeleme üzerinde olmadığından öğrenci anlamakta zorluk çekmiştir. Mete aslında farklı bir uygulama yapmadıklarını ve dengenin bozulmadığını belirterek öğrencinin denklem çözümünü yapısal olarak kavramasını kolaylaştırmaya çalışmıştır. 
Tablo 8. Nisa'nın Birinci Dersinden Bir Bölüm

\begin{tabular}{|l|l|}
\hline Öğrenci & $\begin{array}{l}\text { Hocam şey oluyor aslında. Eşitliğin diğer tarafında da bilinmeyen varsa özdeşlik; tek bir } \\
\text { tarafinda varsa denklem oluyor. Neden buradan hangisi denklem hangisi özdeşlik karar } \\
\text { veremiyoruz? }\end{array}$ \\
\hline Sunum & \\
\hline Nisa & $\begin{array}{l}\text { Aslında öyle karar veremeyiz. Mesela 2x+3=5x-1 olsun. Bak burada da iki bilinmeyen var. } \\
\text { Ama eşitliğin her iki tarafindaki x değerlerine aynı değerleri versem sağlanmaz. Özdeşlik } \\
\text { de hangi değeri verirsen ver eşitliğin sağlanması gerekir. }\end{array}$ \\
\hline Öğrenci & O zaman denklemde yalnız bir özdeşlikte sonsuz değer bulabiliriz. \\
\hline Nisa & $\begin{array}{l}\text { Şöyle ki biz şu anda birinci dereceden denklemlerin üzerinden gittik. Daha sonra ikinci } \\
\text { dereceden denklemleri öğrendiğimizde iki değer de eşitliği sağlayabilecek. Şu şekilde } \\
\text { söylesek daha doğru. Denklemlerde eşitlliği sağlayan değerler sınırlıdır. Özdeşliklerde ise } \\
\text { her sayı için sağlanır. }\end{array}$ \\
\hline Nisa & Tamam mı anlaşıldı mı? \\
\hline Öğrenci & Evet, anlaşıldı hocam. Deneyip anlamaya çalışacağız o zaman. \\
\hline Nisa & Evet, deneyebilirsiniz. Hadi diğer örnekleri de incelemeye devam edelim. \\
\hline
\end{tabular}

Öğretmen adaylarından İpek'e diğer öğretmen adaylarına göre öğrenciler tarafından oldukça az sayıda soru sorulduğu görüldü. Bu duruma neden olarak İpek'in kendisine yöneltilen sorulara detaylı açıklamalar yapmaması ve hızlı bir şekilde derslerine devam etmesi gösterilebilir (Bkz. Tablo 9).

Tablo 9. İpek’in İkinci Dersinden Bir Bölüm

\begin{tabular}{|l|l|}
\hline Sunum & \\
& \\
\hline Öğrenci & $\begin{array}{l}\text { Hocam çizdiğiniz üçgenler mesela sivri uç sağ tarafa bakacak şekilde olsa da eğim aynı } \\
\text { olur değil mi? }\end{array}$ \\
\hline İpek & Evet. Yine aynı işlemi yap değişmez. \\
\hline İpek & Tamam. Çocuklar bakın. Devam edelim. \\
\hline
\end{tabular}


İpek'in öğrencinin sorduğu sorunun üzerinde durmadı̆̆ı bir an önce kaldığı yerden dersine devam ettiği gözlenmiştir. Hızlı bir şekilde derse devam etme isteği öğrencinin sorduğu soruya hatalı cevap vermesine de neden olmuştur. İpek söz konusu üçgenin yönü değiştiğinde eğimin değişmeyeceğini söylemektedir. Hâlbuki üçgenler aynı eğim açılarına sahip olsalar da yönleri farklı olduğundan eğimin işareti değişecek dolayısıyla sonuç farklı olacaktır.

Matematiksel düşünebilmenin temel gerekliliklerinden biri; alana ilişkin dilin doğru kullanımıdır. ÖAB'nin ikinci göstergesi bağlamında öğretmen adaylarının öğretim süreçleri matematik dilini doğru kullanabilmeleri açısından değerlendirildiğinde en çok problem yaşayan öğretmen adayının İpek olduğu sonucuna varılmıştır. İpek bilinmeyen değer veya değişken olarak belirtmesi gereken matematiksel ifadeleri x'li y'li şeyler olarak ifade etmiştir (Bkz. Tablo $10)$.

Tablo 10. İpek’in İkinci Dersinden Bir Bölüm

\begin{tabular}{|l|l|}
\hline İpek & $\begin{array}{l}\text { Evet, burada denklemimiz x'li şeylerden oluşuyor. Biraz önce söylemiştim bunlar } \\
\text { değişebilir. Mesela daha önce a'lı bir denklemi çözmüştük. }\end{array}$ \\
\hline Öğrenci & Hocam birden fazla da oluyor mu denklem içinde? \\
\hline İpek & $\begin{array}{l}\text { Onları da göreceğiz. Ama şimdi bir tanesini bilmediğimiz örneklerle çalışıyoruz. Sonra x'li } \\
\text { y'li şeylerin bir arada olduğu örnekleri de göreceğiz. }\end{array}$ \\
\hline
\end{tabular}

Ayrıca, İpek'in matematiksel ifadeleri sözel olarak tanımlamak yerine "burada" ve "buraya bakıldığında" vb. şeklinde ifade ederek bu konuya yeterince özen göstermediği gözlenmiştir. Diğer öğretmen adaylarıyla karşılaştırıldığında, Mete'nin matematik dilini daha dikkatli kullanmaya özen gösterdiği ve öğrencilerini bu konuda sık sık uyardığı görülmüsşür. İpek'in dersinde görülen matematiksel ifadeyi sözel ifadeye dönüştürme problemi nadir olarak Nisa'nın derslerinde de yaşanmıştır (Bkz. Tablo 11).

Tablo 11. Nisa'nin Üçüncü Dersinden Bir Bölüm

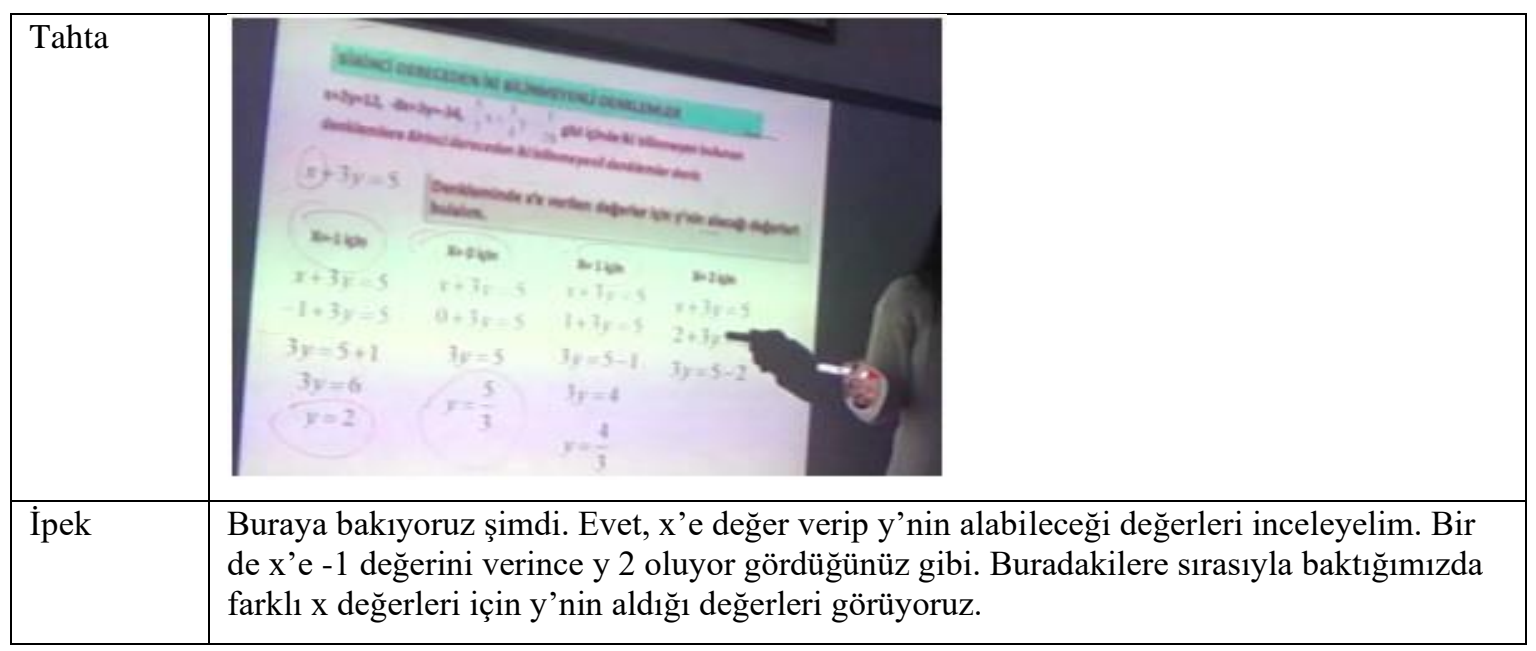

ÖAtB ile ilgili olan önemli bir gösterge de bir öğretmenin daha derin bir matematiksel anlayış oluşturmada yardımcı olma becerisidir. Bu noktada öğretmen adaylarından beklenen üretken matematik soruları sorabilmeleri ve öğrencilerin düşünüşlerini, ihtiyaçlarını ve deneyimlerini hesaba katarak öğretme firsatları yaratabilmeleridir. Ancak Mete ve İpek'in öğrencilerin matematiksel düşünüşlerini genişleten, zorlayan ya da teşvik eden etkili sorular soramadıkları gözlendi.

Öğretmen adaylarının dersleri ÖAB’nin, “Öğretmen adayları öğrencilerin seviyelerini göz önüne alarak derslerinde değişiklikler yapabilirler." göstergesi bağlamında incelenmiştir. Öğrencilerin ilgili konuyu daha iyi anlayabilmeleri için öğretmen adaylarının derslerinde bazı 
değişikliklere yer verdikleri görülmüştür. Genel olarak, bu değişiklikler konuyu tekrar anlatma, değişik materyallerden yararlanma ve örnek soru sayısını arttırma şeklinde gerçekleşti. Öğretmen adaylarının, öğrencilerin anlamakta sorun yaşadığı noktalarda konuyu farklı yöntemlerle başka bir yoldan anlatmak yerine çoğunlukla aynı şekilde tekrar anlattıkları görüldü.

\section{3. Üçüncü Alt Probleme İlişkin Bulgular}

Tablo 12. Alan ve Öğrenci Bilgisi Bileşenine İlişkin Göstergeler

\begin{tabular}{|c|l|}
\hline \multicolumn{1}{|c|}{ Bileşen } & Bileşene İlişkin Göstergeler \\
\hline $\begin{array}{c}\text { Alan ve Öğrenci } \\
\text { Bilgisi }\end{array}$ & $\begin{array}{l}\text { C1. Öğretmenler, öğrencilerin yaygın hatalarını ve kavram yanılgılarını } \\
\text { öngilirler. }\end{array}$ \\
$\begin{array}{l}\text { C2. Öğretmenler, öğrencilerin dikkatini çekebilen onları motive eden çeşitli } \\
\text { örneklere, etkinliklere derslerinde yer verebilirler. } \\
\text { C3. Öğretmenler öğrencilerinin herhangi bir konunun hangi noktasında } \\
\text { zorlanacaklarının farkındadırlar. }\end{array}$ \\
\hline
\end{tabular}

Öğretmen adayları, AÖB'nin birinci göstergesi bağlamında derslerden önce kendileriyle gerçekleştirilen görüşmede, öğrencilerin yapabilecekleri çeşitli hatalar ve sahip olabilecekleri kavram yanılgılarına ilişkin düşüncelerini belirtmişlerdir. Araştırmacı tarafından yöneltilen " 8 . sınıf cebir öğrenme alanına ilişkin öğrencilerin yaygın hataları ve kavram yanılgıları nelerdir? Öğrenciler niçin bu tür hataları yapıyor olabilirler? Hatalar nasıl düzeltilebilir?" sorularına öğretmen adaylarının verdikleri yanıtlar aşağıdaki gibidir:

Öğrenciler en çok ters işlem hataları yapıyorlar. Bazen çarpılması gerekirken böldükleri olabiliyor ya da tam tersi. Bu toplama çıkarmada da görülebilir. Mesela 16x=8 denkleminde bölme yerine çarpma yapan bir özel ders ögrencim olmuştu. Şaşırmadım değil görünce. Başka hımm, işaret hataları olabilir. Eşitliğin karşısına genellikle doğru geçiremiyorlar ifadeyi. Bana kalırsa ögrencileri birçok konuda hataya götüren sahip oldukları kavram yanılgıları aslında. Tabi basit hatalar için söylemiyorum, bazen işaretler unutulabilir, dikkatsizlikten işlem hataları yapılabilir (Mete- Bileşenlere ilişkin görüşme).

Aslına bakarsanız şu an hangi hataları yapabileceklerini bilemiyorum. Ama kâğı̆dıma birkaç soru yazayım. Aa evet soru üzerinden sanırım hangi hatalart yapabileceklerini tahmin edebilirim. Ama söylediklerimin hata mı kavram yanılgısı mı olduğundan şüpheliyim. Yok, bir kavramı yanlış anlamıyla bilmeleri kavram yanılgısıydl. Bu nedenle hata yaparlar. Tamam, mesela öğrenciler işaretleri genelde karıştırtyorlar. Özellikle eksi işaretinde çok hata yapllyyor. Parantezin önünde yer alan eksi işaretinin parantezin içindeki ifadeleri etkileyebileceğini görmezden gelerek soruları çözüyorlar (İpekBileşenlere ilişkin görüşme).

Evet, ögrenciler sahip oldukları kavram yanılgıları nedeniyle çeşitli hatalar yapıyorlar. Aslında ögretmenler bu yanılgıların bilinciyle soru sorabilirlerse sıkıntı kalmaz. Örnek verecek olursam bazen ögrenciler eksi işaretini hiç görmeden işlem yapıyorlar. Yani işlem olarak eksi işaretini kullanıyor ama sayının önünde olunca yine pozitifmiş gibi hareket ediyor. Bir ögrencim böyle yaplyordu özel derste. 7. Sinıfta tam sayılarl iyi anlamadığını düşündüm ve tekrar tam saylları anlattım. Ayrıca eşitliğin diğer tarafina geçirirken de çok problem yaşıyordu. Sürekli neden böyle yaptı̆̆ımızı anlayamadı̆̆ını söylüyordu. Işste aslında bu da eşit işaretinin iyi anlaşılamamasından kaynaklanıyor bence. Eşitlik sonucu bulunca yazmada kullanılan bir sembol olarak biliniyor. Denge anlamı üzerinde durulması gerekiyor (Nisa- Bileşenlere ilişkin görüşme). 
Öğretmen adaylarının söylemleri incelendiğinde, öğrencilerin cebir öğrenme alanına ilişkin yaygın hata ve kavram yanılgıları hakkında sınırlı bilgiye sahip oldukları görülmektedir. Mete öğrencilerin genellikle ters işlem ve işaret hataları yaptıklarını belirtirken, İpek ve Nisa ise öğrencilerin eksi işaretinden kaynaklanan bazı hatalar yaptıklarını belirtmişlerdir.

Öğretmen adaylarının dersleri AÖB'nin ikinci göstergesi bağlamında incelendiğinde öğrencilerin dikkatlerini çeken, derse daha iyi motive olmalarını sağlayan örnek ve etkinliklerden yararlanabildikleri gözlenmiştir. Üç öğretmen adayının söz konusu dersleri incelendiğinde sık sık günlük hayattan örnekler kullandıkları görülmüştür. Özellikle öğretmen adaylarından Mete ve Nisa'nın örüntüler konusuna giriş yaparken kullandıkları örnekler öğrencilerin yoğun ilgisiyle karşılaşmıştır. Öğretmen adaylarından Mete ve İpek'in ise derslerinde öğrencilerin ilgisini çeken etkinliklere yer verdikleri görülmüştür. Mete'nin "Doğrusal denklem sistemlerini cebirsel yöntemlerle çözer." ve "Doğrusal denklem sistemlerini grafikleri kullanarak çözer." kazanımları doğrultusunda hazırladığı "Garfield Zayıflıyor" ve "Ben Bilmem Yeşim Bilir" adlı etkinliklerinin öğrencilerin derse yönelik motivasyonlarının arttırılmasında etkili oldukları görülmüştür. Aynı kazanımlar doğrultusunda İpek'in hazırlamış olduğu "Takipçim Var Ünlüyüm" adlı etkinlik de öğrencilerden yoğun ilgi görmüştür. Her üç etkinlikte yer alan soruların çözümü sırasında da öğrencilerin dersi diğer derslere nazaran daha büyük bir ilgiyle takip ettikleri gözlenmiştir.

AÖB'nin üçüncü göstergesi doğrultusunda, araştırmacı tarafından öğretmen adaylarına "8.sınıf cebir öğrenme alanındaki hangi konuları öğrencilerin anlaması daha uzun zaman alır?" sorusu yöneltilmiştir. Her bir öğretmen adayı, belirttiği konu ya da konuların öğrencilere göre neden zor gelebileceği hakkında ayrıntılı açıklamalar yapmıştır. Öğretmen adaylarının açıklamaları şu şekildedir:

Bence ögrenciler özellikle denklem çözmede çok zorlanırlar. Çünkü burada harfli sembollerin kullanımı söz konusu. İşte, değişken, bilinmeyen kavramları ve eşitlik işaretlerinin anlamı ögrenciler tarafindan iyi anlaşılmalı. Örneğin, harfli ifadelerin farklı değerler alabileceğini anlamakta zorlanabilirler. Sürekli sabit olmadığını iyi anlatmamız gerekir. Özelikle hemen klasik denklem soruları ile başlanırsa öğrenciler zorlanır. Sözel ifadeler kullanarak denklem oluşturma alıştırmaları yapılırsa daha kısa sürede öğrenirler. Onun dışında örüntülerin genel kuralını bulmakta da zorlanırlar. Çünkü sıra sayısı ile terim sayısı arasındaki ilişkiyi bulmak süre isteyebilir. Bazen ben de bulamıyorum (gülüyor) (Mete- Bileşenlere ilişkin görüşme).

Biraz düşünmem lazım, evet öncelikle kendimden yola çıkacağım. Mesela örüntünün kuralını bulmakta zorlandığım oluyor, cebirsel olarak yazmak zamanımı çokça alabiliyor. Şekil üzerinden gitmek lazım ama gerçekten zor sorular var. Ayrıca özel ders ögrencilerime denklem sistemlerini anlatmak baya zamanımı almıştı. Öğrenci katsayısı 1 olan denklemlere yok etme metodunu uygulamakta zorlanmiyor ama I'den farkl olanlarda problem yaşlyor. Ya da bir bilinmeyeni buluyor ama hangi denklemde yerine koyup diğer bilinmeyeni bulacă̆ına karar veremiyor. Yani, hangi denklemde yerine koyarsa koysun sonucun aynı çıkacă̆ın fark edemiyor. Bence öğrenci denklem değişince bilinmeyenin de farklılaşacağını düşünüyor burada. Nedeni bu olabilir. Demek ki sembolleri iyi anlatmamız gerekiyor (İpek- Bileşenlere ilişkin görüşme).

Öğrencilerin çarpanlara ayırma konusunu anlamalar uzun süre alabilir. Öğrenci nereden başlayacağını bilemiyor mesela. Yani, paranteze mi alınacak, nasıl gruplandiracak uzun süre düşünüyor. Tam kare ifadelerde var. Yöntemlerin hepsini düşünmesi gerekiyor. Ayrica denklemleri anlamalar da zaman alabilir. Özellikle işaretlerin neden diğer tarafta değiştiği konusu anlaşılmıyor. Ĕger konunun başında eşitlik kavramı iyi anlatılmazsa sorun olur (Nisa- Bileşenlere ilişkin görüşme).

Öğretmen adaylarından Mete denklemler ve örüntüler, İpek örüntüler ve doğrusal denklemler, Nisa ise özdeşlikler ve denklemler konularında öğrencilerin anlamakta güçlük 
yaşayabilecekleri noktalara değinmişlerdir. Ayrıca Mete ve İpek öğrencilerin örüntülerin genel kuralını cebirsel olarak ifade etmede problem yaşayabileceklerini düşünmektedirler.

\subsection{Dördüncü Alt Probleme İliş̧kin Bulgular}

Tablo 13. Alan ve Öğretme Bilgisi Bileşenine İlişkin Göstergeler

\begin{tabular}{|c|l|}
\hline Bileşen & Bileşene İlişkin Göstergeler \\
\hline $\begin{array}{l}\text { D1. Öğretmenler, dersin hedeflerine uygun plan hazırlayabilirler ve planları } \\
\text { doğrultusunda derslerini gerçekleştirebilirler. }\end{array}$ \\
$\begin{array}{c}\text { Alan ve } \\
\text { Öğğ Öğretmenler, derslerinde uygun strateji, yöntem ve tekniklerden yararlanabilirler. }\end{array}$ \\
$\begin{array}{l}\text { D3. Öğretmenler öğrencileri kazanımlara ulaştırmada etkili olabilecek ders } \\
\text { materyallerini seçebilirler ve amaca uygun bir şekilde kullanabilirler. }\end{array}$
\end{tabular}

AÖB'nin birinci göstergesi bağlamında araştırmacılar tarafından herhangi bir müdahalede bulunulmamasına rağmen, her bir öğretmen adayının söz konusu kazanımlar doğrultusunda gerçekleştirecekleri derslere ilişkin planlarını hazırlayabildikleri görülmüştür. Öğretmen adayları ortaokul matematik dersi öğretim programı aracılığıyla derslere ilişkin kazanımların neler olduğu, kazanımların içeriği ve dikkat edilmesi gereken noktalar hakkında çeşitli bilgilere ulaştıklarını belirtmişlerdir. Bununla uyumlu olarak, üç öğretmen adayı da hazırlamış oldukları ders planlarında derslerle ilgili kazanımları, öğrenme-öğretme yöntem ve tekniklerini, yararlanılacak ders materyallerini, öğrenme-öğretme süreçlerine yönelik etkinlikleri ve derslerin diğer derslerle ilişkisini detaylı olarak açıklayabilmişlerdir. Ancak, öğretmen adaylarının bazı derslerde gelişen beklenmedik durumlar sebebiyle planlarının dışında hareket etmek durumunda kaldıkları gözlenmiştir. Örneğin, öğretmen adayı Nisa ders planında yer verdiği ama öğretim süreci esnasında uygulayamadığı bir etkinliği olduğunu belirtmiş ve bu duruma neden olarak ders süresini ayarlayamamasını göstermiştir.

Öğretmen adaylarının dersleri AÖtB'nin ikinci göstergesi 1şı̆̆ında genel olarak incelendiğinde en fazla kullanılan yöntemlerin düz anlatım ve soru-cevap teknikleri olduğu görülmüştür. Özellikle konu anlatımı sırasında yoğun olarak düz anlatım yöntemi tercih edilmiștir. Bununla beraber, soru-cevap tekniği eski konuları hatırlatırken, ders anlatımı sırasında, ders anlatımının hemen sonrasında soru çözümü yaparken ya da ders bitiminde konuyu kimlerin anlayıp anlamadığını tespit ederken kullanılmıştır. Mete soru-cevap ve düz anlatım tekniklerinin yanı sıra ikinci dersinin sonunda pazaryeri, dördüncü dersinin sonunda ise istasyon tekniğine yer vermiştir. İpek, ders planında istasyon tekniğini kullanacağını belirtmesine rağmen süre yetersizliğinden dolayı teknikten yararlanamamıştır. Öğretmen adayı Nisa ise derslerinde soru-cevap ve düz anlatım tekniği haricinde farklı bir teknikten yararlanmamıştır.

Öğretmen adaylarının dersleri AÖtB'nin üçüncü göstergesi bağlamında genel itibariyle incelendiğinde planlarında belirttikleri ders materyallerini sınıfta kullanabildikleri gözlenmiştir. Üç öğretmen adayı da ders anlatımlarını hazırladıkları sunum aracılığıyla gerçekleştirmeyi tercih etmiştir. Sunumlarda kullandıkları örnek soru ve açıklamalar için genellikle ders kitabından yararlandıklarını ifade etmişlerdir. Ayrıca, Mete kullandığı bazı sorular için test kitaplarından da yararlandığını belirtmiştir. Öğretmen adaylarından Mete ve İpek, etkinlik ve çalışma yaprakları hazırlama sürecinde internet kaynakları ve lisans öğrenimlerinde yaptıkları çalışmalardan da yararlandığını belirtmiştir. Nisa ise kullandığı çalışma yaprağını daha önce hazırladığını ve yeni bir çalışma yapmadığını ifade etmiştir.

Çok fazla kaynaktan yararlandım ama en çok ders kitabından sanırım. Diğer kaynaklardan işte test kitaplarından da yararlandım, soru alırken de kitaptaki örneklerle karşılaş̧ırdım. Her türlü soru çeşidini koymak istedim etkinliklerime, çalışma yapraklarına. Onun dışında üniversite de özel öğretim yöntemleri dersinde yaptı̆̆ımız 
etkinlikler ve çalışma yapraklarından yararlandım. İnternettekilere de baktım. ... (MeteDerslere yönelik genel görüşme).

Sunumda kullandığım görsel ve açıklamaların büyük kısmını 8. sınıf ders kitabından aldım. Açıkçası en doğru bilgi burada diye çok fazla kaynaktan yararlanmayı düşünmedim. Soruları da ders kitabında bulunan alıştırmalardan aldım. Ama bir kısmının üzerinde benim de oynamalar yaptığım oldu. Etkinlik için internetten araştırma yaptım, çok içime sinen olmadı. Bazılarının sorularından yararlanarak kendim oluşturdum etkinliğimi. Hatta özel ögretim yöntemlerinde hazırladı̆̆ımız etkinlikler de vardı. Onların sorularını da kullandım... (İpek-Derslere yönelik genel görüşme).

Birçok şeyi kullandım aslında. Sunumdakiler için ders kitabından alıntılar yaptım. Öğrencilere vermem gereken bilgiler olabilir diye ders kitabından pek uzaklaşmadım. Çalışma yaprağım hazırdı, geçen yıl grup ödevimizdi... (Nisa-Derslere yönelik genel görüşme).

Öğretmen adayları ayrıca cebir öğrenme alanına ilişkin konuların daha iyi anlaşılması için derslerinde kullandıkları materyallere dair şu açıklamalarda bulunmuşlardır:

Konunun daha iyi anlaşılması için derslerimde sunumdan yararlandım. Çünkü görsellerin önemli olduğunu düşünüyorum. Tabi beni yazma işinden de kurtardl. Daha hizlı ilerleyebildim. Eşitliğin denge durumunu anlatmakta bir askıdan yararlandım. Terazi gibi kullandım. Bunu internette görmüşüm. Sanırım faydalı oldu. Başka, evet, cebir karolar tabi ki. Öğretim programında da öneriliyor. Kesinlikle özdeşlik ve çarpanlara ayırma konularında çok işime yaradı. Konuları öğrencilere cebir karolarıla anlattıktan sonra çalı̧̧ma yaprağı dağıttım. Buradaki modellerin cebirsel ifadesini yazmakta zorlanmadılar. Yani, düşünüyorum da çalışma kağıdı yerine cebir karolarını da ögrencilere dağıtabilirdim. Ama işte sınıfta çok fazla gürültü oluyor. Dersten kopmalar falan... (Mete- Derslere yönelik genel görüşme).

Cebir için kullanılacak materyal sınırlı bence. Belki de benim eksiğim bu. Sinıfa cebir karoları haricinde bir şey getirmedim. Zaten sunumda her şey vardl. Hatta cebir karolarını da getirdim ama kullanmadım. Çünkü sunumda hazırladığım modeller işimi gördü. Öğrenciler soruları cevapladı. Çalışma yaprağını hızlı bir şekilde tamamladılar Medcezir etkinliği de kesinlikle doğrusal denklemler konusunun daha iyi anlaşılmasını sağladı...(İpek- Derslere yönelik genel görüşme).

Cebir karolarını kullandım. Öğrenciler özdeşlikler ve çarpanlara ayırmayı sevdiler böylelikle. Bir de eğim konusunda farklı üçgenler oluşturmak için geometri tahtasından yararlandım. Kenar uzunluklarl değiş̧ikçe eğim de ki değişimi görmelerini istedim. İşte, sunumumdaki resimler de çok işe yaradı. Ögrenciler hani daha bir ilgiyle takip ettiler. Ek olarak öğrencilerin öğrendiklerini pekiştirmeleri için çalışma kâğıdı kullandım...(NisaDerslere yönelik genel görüşme).

Öğretmen adaylarının dersleri ve ifadeleri genel olarak değerlendirildiğinde, materyallerini dersin kazanımları doğrultusunda kullanabildikleri söylenebilir. Üç öğretmen adayı da özdeşlik ve çarpanlara ayırma konularında cebir karoları kullanımının önemli olduğunu belirtmişlerdir. Ayrıca, Nisa'nın üçgenlerin dik kenarlarının uzunlukları değiştikçe eğimin nasıl değiştiğini açıkladığı dersinde geometri tahtasından faydalandığı görülmüştür. Diğer öğretmen adayı Mete ise birinci dereceden bir bilinmeyenli denklemler konusuna girişte bir elbise askısını terazi gibi kullanarak eşitlik işaretinin denge göstergesi olduğunu belirtmeye çalışmıştır.

Araştırmanın veri toplama araçları olan Bileşenlere İlişkin Görüşme Formu, derslerin video kayıtlarını içeren Gözlem Formu ve Derslere Yönelik Genel Görüşme Formu aracılığıyla öğretmen adayları hakkında elde edilen tüm veriler araştırmanın sonunda birlikte değerlendirilerek analiz edilmiştir. Elde edilen sonuçlara göre, öğretmen adaylarının alan ve pedagojik alan bilgi düzeyleri ÖMB modelinin göstergeleri 1şığında Tablo 14'de özetlenmiştir. 
Tablo 14. Öğretmek İçin Matematiksel Bilgisi Modeline Göre Öğretmen Adaylarının Alan ve Pedagojik Alan Bilgi Düzeyleri

\begin{tabular}{|c|c|c|c|}
\hline BİLEŞENLER VE GÖSTERGELERİ & METE & İPEK & NiSA \\
\hline Genel Alan Bilgisi & & & \\
\hline $\begin{array}{l}\text { A1. Öğretmenler, çeşitli hesaplamaları ve problemleri } \\
\text { doğru bir şekilde cevaplayabilirler. }\end{array}$ & IV & III & III \\
\hline $\begin{array}{l}\text { A2. Öğretmenler, öğrencilerin yaptıkları hataları fark } \\
\text { edebilirler. }\end{array}$ & V & IV & V \\
\hline $\begin{array}{l}\text { A3. Öğretmenler, matematiksel ifadeleri ve terimleri } \\
\text { doğru bir şekilde kullanırlar. }\end{array}$ & $\mathrm{V}$ & $\mathrm{V}$ & $\mathrm{V}$ \\
\hline Uzmanlık Alan Bilgisi & & & \\
\hline $\begin{array}{l}\text { B1. Öğretmenler, öğrencilerin soru ve cevaplarını } \\
\text { nedenleriyle birlikte açıklayabilirler. }\end{array}$ & V & I & V \\
\hline $\begin{array}{l}\text { B2. Öğretmenler, matematik alan dilini doğru bir şekilde } \\
\text { kullanabilirler. }\end{array}$ & $\mathrm{V}$ & II & IV \\
\hline $\begin{array}{l}\text { B3. Öğretmenler, öğrencilere ulaşılması hedeflenen } \\
\text { kazanımlar doğrultusunda üretken matematik soruları } \\
\text { yöneltebilirler. }\end{array}$ & II & II & IV \\
\hline $\begin{array}{l}\text { B4. Öğretmenler, öğrencilerin seviyelerini göz önüne } \\
\text { alarak öğrenim sürecinde değişiklikler yapabilirler. }\end{array}$ & III & II & III \\
\hline Alan ve Öğrenci Bilgisi & & & \\
\hline $\begin{array}{l}\text { C1. Öğretmenler, öğrencilerin yaygın hatalarını ve } \\
\text { kavram yanılgılarını öngörebilirler. }\end{array}$ & IV & II & III \\
\hline $\begin{array}{l}\text { C2. Öğretmeler, öğrencilerin dikkatini çekebilen onları } \\
\text { derse motive eden çeşitli örneklere, etkinliklere } \\
\text { derslerinde yer verebilirler. }\end{array}$ & $\mathrm{V}$ & V & IV \\
\hline $\begin{array}{l}\text { C3. Öğretmenler, öğrencilerin herhangi bir konunun } \\
\text { hangi noktasında zorlanacaklarının farkındadırlar. }\end{array}$ & V & V & IV \\
\hline Alan ve Öğretim Bilgisi & & & \\
\hline $\begin{array}{l}\text { D1. Öğretmenler dersin hedeflerine uygun plan } \\
\text { hazırlayabilirler ve planları doğrultusunda derslerini } \\
\text { gerçekleştirebilirler. }\end{array}$ & $\mathrm{V}$ & $\mathrm{V}$ & IV \\
\hline $\begin{array}{l}\text { D2. Öğretmenler derslerinde uygun strateji, yöntem ve } \\
\text { tekniklerden yararlanabilirler. }\end{array}$ & V & IV & III \\
\hline $\begin{array}{l}\text { D3. Öğretmenler, öğrencilerini kazanımlara ulaştırmada } \\
\text { etkili olabilecek ders materyallerini seçebilirler ve amaca } \\
\text { uygun bir sekilde kullanabilirler. }\end{array}$ & $\mathrm{V}$ & IV & V \\
\hline
\end{tabular}

\section{TARTIŞMA, SONUÇ VE ÖNERILER}

Bu çalışmada ortaokul matematik öğretmen adaylarının cebir öğrenme alanına ilişkin alan ve pedagojik alan bilgileri "Öğretmek İçin Matematik Bilgisi" (ÖMB) kuramsal çerçevesi kulanılarak incelenmiştir. Söz konusu inceleme neticesinde öğretmen adaylarının "Genel Alan 
Bilgisi” (GAB), "Uzmanlık Alan Bilgisi” (UAB), "Alan ve Öğrenci Bilgisi” (AÖB) ve "Alan ve Öğretme Bilgisi" (AötB) hakkında detaylı bilgiler edinilmiştir. Öğretmen adaylarının herbir bileşene ilişkin çeşitli bilgi eksiklikleri olmakla birlikte bilgi eksikliklerinin özellikle UAB bileşenlerinde yoğunlaştığı sonucuna ulaşılmıştır.

\subsection{Genel Alan Bilgisi}

GAB'nin "Öğretmenler çeşitli matematiksel hesaplamaları ve problemleri doğru bir şekilde cevaplayabilirler" göstergesine göre öğretmen adaylarının çeşitli matematiksel hesaplamaları ve problemleri genel itibariyle doğru cevaplayabildikleri görülmüştür. Adaylar sınırlı sayıda da olsa bazı soruları cevaplamakta sıkıntı yaşamışlardır. Ryan ve McCrae (2006) çalışmalarında, çeşitli matematik sorularını yanıtsız bırakmanın ve yapılan hataların, adayların GAB'ndeki eksikliğe işaret ettiğini vurgulamaktadırlar. Bu bağlamda öğretmen adaylarının GAB'nde eksikliklerin olduğu söylenebilir. Literatürde öğretmen adaylarının GAB'nin yetersiz olduğunu tespit eden çalışmalar mevcuttur (Aslan Tutak, 2009; Ball, 1990). Ball (1990) çalışmasında incelediği öğretmenlerin GAB'nin yeterli olduğunu belirlemesine rağmen derinlemesine bir GAB'ne sahip olmadıklarını belirtmiştir.

GAB'nin “Öğretmenler öğrencilerin yaptıkları hataları fark edebilirler.” göstergesi bağlamında öğretmen adaylarının söylemleri ve davranışları göz önüne alındığında üç öğretmen adayının da çoğunlukla öğrencilerin hatalarını fark edebildikleri gözlenmiştir.

GAB'nin diğer bir göstergesi "Öğretmenler, matematiksel ifadeleri ve terimleri doğru bir şekilde kullanırlar." şeklindedir. Bu doğrultuda, öğretmen adaylarının dersleri incelendiğinde üç öğretmen adayının da hazırlamış oldukları sunumlarda ve tahta kullanımlarında matematiksel ifadeleri doğru kullanmaya dikkat ettikleri gözlenmiştir. Öğretmen adayları ayrıca 8. sınıf cebir öğrenme alanına ilişkin terimlerin tanımlarına derslerinde yer vermişler ve terimleri doğru bir şekilde ifade etmeye özen göstermişlerdir. Üç öğretmen adayının da terimlerin açıklamalarına derslerinde yer verip örnek sorularla pekiştirmek istemeleri, tanımları öğrenme süreci üzerinde etkili gördüklerini düşündürmektedir. Van den Kieboom (2013), öğretmen adaylarının matematik öğretim bilgilerini araştırdığı çalışmasında GAB'ni “Öğretmen adayları öğrettikleri matematiksel terim ve kavramları iyi bir şekilde anlamalı ve kurdukları problemlerin çözümünde doğru bir şekilde kullanabilmelidirler." şeklinde ifade etmiştir. Dolayısıyla öğretmen adaylarının cebire ilişkin matematiksel terim ve kavramları doğru bir şekilde kullanabiliyor olmalarının genel alan bilgilerinin değerlendirilmesi noktasında önemli olduğu söylenebilir.

\subsection{Uzmanlık Alan Bilgisi}

Öğretmen adaylarının gözlemlenen dersleri ve kendileriyle gerçekleştirilen görüşmeler UAB'nin göstergeleri bağlamında incelenmiştir.

UAB'nin "Öğretmenler, öğrencilerin soru ve cevaplarını nedenleriyle birlikte açıklayabilirler." göstergesi kapsamında katılımcıların öğretim süreçleri değerlendirildiğinde Mete ve Nisa'nın, öğrenci sorularına daha fazla zaman ayırdıkları ve öğrencilerin yanıtlarını detaylı bir şekilde ele aldıkları gözlenirken İpek'in derslerinde ise tam tersi bir durum gözlenmiştir. İpek genellikle öğrencilerin kendisine yönelttikleri sorulara fazla zaman ayırmayıp dersine devam etme eğiliminde olmuştur. İpek'in bazı öğrenci sorularını hatalı cevapladığı da gözlenmiştir. Bu durum öğretmen adayının öğrenci yanıtlarını derinlemesine bir anlamlandırma sürecine alamadığını göstermektedir. Literatürdeki bazı çalışmalarda da bu yönde sonuçlara ulaşılmıştır (Even ve Markovits, 1995; Even ve Tirosh, 1995; Tirosh, 2000). Hill de (2007) çalışmasında ortaokul matematik öğretmenlerinin öğrencilerin soru ve cevaplarını, farklı çözüm yöntemlerini nedenleriyle birlikte yanıtlayabilecek kadar yeterli olmadıklarını belirtmiştir. Hill ve Lubienski (2007), UAB'nin kavram ve algoritmalara yönelik açıklamalar ve nedenler sunulabilmesini ve öğrencilerin çalışmalarına yönelik matematiksel değerlendirmeler yapılabilmesini içerdiğini belirtmişlerdir. Toluk Uçar (2011) araştırmasında öğretmen adaylarının genellikle işlemsel anlamaya ilişkin açıklamalar yapabildiklerini ve açıklamalarını gerekçelendirmede yetersiz kaldıklarını tespit etmiştir. İpek'in özel alan bilgisindeki 
yetersizlikler öğrenci sorularını fazla önemsememesine, hatalı yanıtlar vermesine ve öğrenci hatalarının nedenlerini derinlemesine yorumlayamamasına neden olmuş olabilir.

UAB'nin ikinci göstergesi olan "Öğretmenler matematik alan dilini doğru bir şekilde kullanabilirler." kapsamında katılımcıların öğretim süreçleri incelendiğinde öğretmen adaylarından Mete'nin matematik alan dilini kullanmada çok dikkatli davrandığı ve matematiksel ifadeleri sözel ifadelere çevirmede herhangi bir problem yaşamadığ 1 görülmüştür. Yeşildere'ye (2007) göre öğretmenin sahip olduğu alan bilgisi düzeyi, matematiksel dilin doğru kullanımı üzerinde etkilidir. Bu doğrultuda öğretmen adayı Mete'nin en yüksek lisans başarı ortalamasına sahip olması ve diğer öğretmen adaylarına nispeten GAB'ne yönelik göstergeler bağlamında daha iyi bir performans sergilemesi matematiksel dili doğru kullanmasında etkili olmuş olabilir.

UAB’nin üçüncü göstergesi “Öğretmenler öğrencilere ulaşılması hedeflenen kazanımlar doğrultusunda üretken matematik soruları sorabilirler." çerçevesinde öğretmen adaylarından beklenen öğrencilerin düşünüşlerini, ihtiyaçlarını ve deneyimlerini hesaba katarak öğretme firsatlar1 yaratabilmeleridir. Özkan'a (2011) göre sınıf içi öğretimin öğrenme üzerinde etkili olmasını ve öğretimin niteliğini arttıran en önemli unsur öğrencilere sorulan sorulardır. Derin matematiksel düşünüş oluşturmaya yönelik sorular öğrencilerin matematiksel genellemeler geliştirmelerine, kanıtlamalarına ve kullanmalarına yardımcı olmaktadır (Russell, 1999). Bu doğrultuda, böylesine önemli olan bir eylemin doğru seçimler yapılarak düzenlenmesi gerektiği söylenebilir. Öğretmen adaylarının dersleri incelendiğinde Nisa'nın soru sormayı diğer öğretmen adaylarına göre daha etkili kullandığı sonucuna ulaşılmıştır. Nisa'nın, öğrencilerin düşüncelerinden yararlanarak yönelteceği soruları şekillendirdiği ve kuralları bir an önce vermek yerine öğrenciler tarafindan hissedilmesini sağladığı görülmüştür. Matematik eğitimi üzerinde çalışan birçok araştırmacı da öğrencilerin matematiksel düşünüşleri üzerine odaklanmanın önemini vurgulamıştır (Ginsburg ve Amit, 2008; NCTM, 2000; Russell, 1999). Mete ve İpek'in ise öğrencilerin matematiksel düşünüşlerini genişleten, zorlayan ya da teşvik edebilen soruları sormakta sıkıntı yaşadıkları genellikle derslerinde işlemlerin sonucunu bulmaya yönelik ve evet-hayır gibi kısa yanıtlar verilmesini gerektiren sorular sormayı tercih ettikleri gözlenmiştir. Bu alandaki bir başka araştırmada da öğretmenlerin genellikle öğrenilmiş bilgilerin tekrarını ortaya koyan nitelikte kısa cevaplı sorular sorma eğiliminde olduğu sonucuna varılmıştır (Teachervision, 2010'dan akt., Özkan, 2011).

UAB'nin bir diğer göstergesi “Öğretmenler öğrencilerinin seviyelerini göz önüne alarak öğretim sürecinde değişiklikler yapabilirler” kapsamında öğretmen adaylarından beklenen öğrencilerinin öğretim süreçlerindeki durumlarını gözlemleyerek ilgili konuyu daha iyi anlayabilmeleri için derslerinde bazı değişikliklere gidebilmeleridir. Öğretmen adaylarının derslerinde üç tür değişiklik görülmüştür. Bu değişiklikler konuyu tekrar anlatma, örnek soru sayısını arttırma ve değişik materyallerden yararlanma şeklindedir. Matematik derslerinde konuyu tekrar anlatma yaklaşımı öğretmenlerce oldukça sık tercih edilmektedir (Budak, Budak, Tutak ve Dane, 2009). Sınıf ortamında çözülen soruların sayısı artıkça öğrencilerin konuları öğrenme oranı da artmaktadır (Gage ve Berliner, 1994). Öğretim materyalleri ile desteklenen dersler öğrencilerin öğrenmelerini kolaylaştırır (Arslan, 2003; İnan, 2006; Tabuk, 2003). Öğretmen adayları materyal kullanımıyla öğrencilerin ilgili konuları daha iyi anladıklarını belirtmişlerdir. Materyal kullanımı uygulama yaparken öğretmene yardımcı olur, öğrencilerin istenilen kazanıma daha kısa sürede ulaşmalarını destekler (Koşar ve diğerleri, 2003). Öğretmen adaylarının, öğrencilerin anlamakta sorun yaşadığı noktalarda konuyu çoğunlukla tekrar anlattıkları görülmüştür. Tekrar anlatım metodunun üç öğretmen adayı tarafından da sıklıkla kullanılmasına sebep olarak matematiksel kavramlar ve bu kavramları farklı yollardan öğretme yöntemleri hakkında kısıtlı bilgiye sahip olmaları gösterilebilir.

\subsection{Alan ve Öğrenci Bilgisi}

AÖB'nin birinci göstergesi olan “Öğretmenler, öğrencilerin yaygın hatalarını ve kavram yanılgılarını göz önünde bulundurarak derslerinde bunları engelleyici yaklaşımlarda 
bulunabilirler." kapsamında öğretmen adaylarıyla gerçekleştirilen görüşmelerin yazıya aktarımları ve öğretim süreçleri incelenmiştir. Öğretmen adaylarının literatürde yer alan kavram yanılgıları ve yaygın öğrenci hatalarına ilişkin sınırlı bilgiye sahip oldukları görülmüştür. Öğretmen adaylarından Mete ve Nisa öğrencilerin sahip olabilecekleri kavram yanılgılarının sebeplerini genel itibariyle kavramların derin bilgisine hâkim olmamalarına bağlamaktadırlar. Çeşitli araştırmalar da cebirsel kavramların (eşitlik, denklem, cebirsel ifadeler, değişkenler) anlaşılması ile ilgili güçlükler ve kavram yanılgıları olduğunu belirtmektedir (English ve Halford, 1995; Kieran, 1990; MacGregor ve Stacey, 1993). Öğretmen adaylarının derslerinde özellikle değişken kavramının kavramsal yönü üzerinde durarak olası kavram yanılgılarını en aza indirebilme gayreti içerisinde oldukları görülmüştür. Bu sonuç Ersoy ve Erbaş'ın (2005) çalışmalarıyla farklılık göstermektedir. Ersoy ve Erbaş (2005) öğretmenlerin derslerinde genellikle değişken kavramının kavramsal yönünü ihmal edip işlemsel yönüne vurgu yapmışlardır. Üç öğretmen adayı ayrıca eşitlik kavramının tam olarak anlaşılamamasından kaynaklanan bazı hataların yapılabileceğini belirmişlerdir. Carpenter'e (2003) göre eşitlik işaretinin anlamı hakkında sınırlı olan kavramalar cebir öğretiminin en önemli engellerinden birisidir. İpek bu duruma yönelik herhangi bir çözüm önerisinde bulunmazken Mete bunun terazi örneği üzerinden anlatılabileceğini önermiş, Nisa ise eşitlik sembolüne verilen anlama odaklanılması gerektiğini belirtmiştir. Herscovics ve Kieran (1980) eşitlik işaretinin "işlem yap, sonucu bul" anlamından uzaklaştırılıp ifadeler arasındaki denklik sembolü olarak görülmesi gerektiğini belirtmişlerdir. Öğretmen adaylarının derslerini de söylemleri doğrultusunda gerçekleştirdikleri görülmüştür. İpek' in cebir öğrenme alanına ilişkin literatürde yer alan hata ve kavram yanılgısı bilgilerinin oldukça sınırlı olması öğretim sürecine de yansımıştır. Grouws ve Schultz (1996) öğretmenlerin öğrencilerde olması muhtemel kavram yanılgıları konusunda detaylı bilgilerinin olması halinde öğretimlerini ona göre düzenleyebileceklerini belirterek hata ve kavram yanılgılarına ilişkin kısıtlı bilginin öğretim süreci üzerindeki olumsuz etkisinden söz etmiştir.

AÖB'nin ikinci göstergesi olan “Öğretmenler öğrencilerin dikkatini çekebilen onları motive eden çeşitli örneklere, etkinliklere derslerinde yer verebilirler." kapsamında öğretmen adaylarından elde edilen bilgiler incelendiğinde öğrencilerin dikkatlerini çeken, derse daha iyi motive olmalarını sağlayan örnek ve etkinliklerden yararlanabildikleri gözlenmiştir. Öğretmen adaylarının verdikleri örneklerin günlük yaşamla ilişkilendirilmiş olması öğrencilerin ilgisini çekmekte etkili olmuştur. Garil ve Silverman (2009) öğretmenlerin derslerde, günlük hayat ile matematik arasında bağlantı kurarken çeşitli sıkıntılar yaşadıklarını belirtmiştir. Ancak, çalışmada yer alan öğretmen adayları bu konuda herhangi bir problem yaşamamışlardır. Milli Eğitim Bakanlığı (MEB) matematik eğitiminin genel amaçlarında öğrenilen bilgilerin günlük yaşamla ilişkilendirilmesinin önemi üzerinde durmaktadır (MEB, 2008). Öğretmen adaylarından Mete ve İpek'in yapılandırmacı anlayışa uygun olarak hazırlayıp derslerinde kullandıkları etkinliklerin öğrencilerin derse yönelik motivasyonlarını ve öğrenilen bilgilerin kalıcılığının arttırdıkları görülmüştür. Öğretim programına göre düzenlenmiş etkinliklerin doğru bir şekilde uygulanması, öğrenmenin kalıcılığı üzerinde etkilidir (Özmantar, Bozkurt, Demir, Bingölbali ve Aç1l, 2010; Ubuz, Erbaş, Çetinkaya ve Özgeldi 2010; Uğurel ve Bukova Güzel, 2010). Bu bağlamda günlük yaşamla ilişkilendirilmiş düşündürücü sorular, dikkat çekici çizim, grafik ve resim gibi unsurlarla zenginleştirilmiş etkinliklerden yararlanılması öğrencilerin öğrenme süreçlerinde faydalı olabilir.

AÖB'nin üçüncü göstergesi “Öğretmenler, öğrencilerinin herhangi bir konunun hangi noktasında zorlanacaklarının farkındadırlar." çerçevesinde öğretmen adaylarının bilgileri değerlendirilmiştir. Bu gösterge kapsamında öğretmen adaylarından beklenen öğrencilerinin neyi yapıp neyi yapamayacakları hakkında fikir sahibi olabilmeleridir. Öğretmen adayları öğrencilerin denklemler, örüntüler, doğrusal denklemler ve özdeşlikler konularını anlamakta güçlük yaşayabileceklerini ifade etmişlerdir. Üç öğretmen adayı da öğrencilerin özellikle denklem çözümleri yaparken zorlanacaklarını belirtmişlerdir. Ersoy ve Erbaş (2002) araştırmalarında, öğrencilerin denklem (eşitlik) kurma ve çözmedeki başarısı ve buna bağlı 
olarak yaşadıkları güçlükleri incelemişlerdir. Araştırmada, öğrencilerin cebir öğreniminde bir takım zorluklarla karşılaştıkları belirtilmiş ve bu zorlukları giderici çalışmaların yapılması gerektiği önerilmiştir. Çeşitli çalışmalar farklı okul ve sınıf düzeylerindeki öğrencilerin denklem kurma ve çözme süreçlerinde güçlük yaşadıklarını göstermiştir (Dede ve Peker, 2007; English ve Halford, 1995; MacGregor ve Stacey, 1993). Ayrıca Mete ve İpek öğrencilerin örüntülerin genel kuralını cebirsel olarak ifade etmede problem yaşayabilecekleri ifade etmiştir. Yeşildere ve Akkoç (2010), öğrencilerin sayı örüntülerinin kuralını cebirsel olarak ifade etmede güçlük çektiklerini belirtmiştir. Bu doğrultuda, farklı sınıf seviyelerindeki öğrencilerin ve öğretmen adaylarının örüntüleri algılayışları ve genellemeleri ile ilgili çok sayıda araştırma yapılmıştır (Tanışlı ve Yavuzsoy Köse, 2010; Yaman, 2010; Yeşildere ve Akkoç, 2010). Orton ve Orton (1999) öğrencilerin örüntü oluşturma becerilerini inceledikleri çalışmada sayı örüntülerini genellemenin cebir için oldukça önemli olduğunu belirtmişlerdir. Dede, Yalın ve Argün (2002) tarafından gerçekleştirilen çalışmanın sonuçları da öğrencilerin değişken kavramını anlamakta oldukça zorlandıklarını dolayısıyla da örüntüleri kavramakta sıkıntı yaşadıklarını ortaya koymuştur. Literatürdeki çalışmalar göz önüne alındığında öğretmen adaylarının öğrencilerin hangi konularda zorluk yaşayabileceklerine dair doğru çıarımlarda bulundukları söylenebilir.

\subsection{Alan ve Öğretme Bilgisi}

AÖtB'nin birinci göstergesi “Öğretmenler dersin hedeflerine uygun plan hazırlayabilirler ve planları doğrultusunda derslerini gerçekleştirebilirler." çerçevesinde öğretmen adaylarından elde edilen bilgiler incelendiğinde ortaokul matematik dersi öğretim programında yer alan kazanımları ve bu kazanımların sırasını temel alarak gerçekleştirecekleri her bir derse ilişkin planları hazırlayabildikleri görülmüştür. Bu noktada, araştırmacılar tarafından herhangi bir müdahalede bulunmaksızın öğretmen adaylarının derslerin kazanımlarına uygun planlar hazırlayabilmelerinde resmi öğretim programının kolaylaştırıcı etkisi olduğu söylenebilir. Öğretmenler planlarını öğretim programı çerçevesinde yapar (İşman ve Eskicumalı, 2003'den akt., Öztürk 2012). Öğretmen adaylarının bazı derslerde planlarının dışında hareket ettikleri gözlenmiştir. Söz konusu plan değişikliklerinde adayların sınıf yönetiminde yaşadıkları problemlerin etkili olduğu söylenebilir. Bu doğrultuda Aydın'ın (2007) belirttiği gibi bir öğretmenin sınıf yönetimi konusunda yetkin olması gerekmektedir. Öğretmen adaylarının yaşadıkları problemlere neden olarak gerçek sınıf ortamında öğretim yapmamalarından kaynaklanan deneyim eksiklikleri gösterilebilir. Yeşildere ve Akkoç (2010) öğretmen adaylarının gerçek sınıf ortamında deneyim yaşayabilmelerinin mümkün olmadığı durumlarda mikro öğretim etkinliklerinden yararlanılabileceğini belirtmişlerdir.

AÖtB'nin ikinci göstergesi olan "Öğretmenler derslerinde uygun strateji, yöntem ve tekniklerden yararlanabilirler.” kapsamında öğretmen adaylarının öğretim süreçleri değerlendirildiğinde öğretmen adayları tarafindan en fazla tercih edilen yöntemlerin soru- cevap ve düz anlatım teknikleri olduğu gözlenmiştir. Başer ve Narlı da (2003) matematik öğretmenlerinin öğretim yöntemlerindeki sorunları araştırdıkları çalışmalarında benzer bir sonuca ulaşmışlardır. Çalışmanın sonuçlarına göre ilköğretim matematik öğretmenleri matematik öğretiminde düz anlatım yöntemine oldukça önem vermektedirler. Bu duruma neden olarak öğretmen adaylarının öğrenim süreçlerinde genellikle bu yöntemlerden yararlanılarak derslerin işlenmiş olması gösterilebilir. Öğretmenlerin öğrencilik deneyimleri ve geçmiş matematik öğretmenleri öğretim süreçleri üzerinde etkili olabilmektedir (Borko ve diğerleri, 1992; Raymond, 1997). Üç öğretmen adayının da soru cevap tekniğinden yararlandıkları görülmüştür. Özkan (2011) öğretim ortamında farklı niteliklerde sorular sorulabileceğini ve farklı nitelikteki soruların farklı davranışların kazanılmasını sağladığını belirtmiştir. Katılımcıların farklı öğretim yaklaşımlarından genellikle uzak durdukları görülmüştür. $\mathrm{Bu}$ duruma neden olarak öğretmen adaylarının sınıf ve zaman yönetimi konularındaki deneyim eksiklikleri gösterilebilir.

AÖtB'nin üçüncü göstergesi olan "Öğretmenler öğrencileri kazanımlara ulaştırmada etkili olabilecek ders materyallerini seçebilirler ve amaca uygun bir şekilde kullanabilirler." bağlamında öğretmen adaylarının öğretim süreçleri incelendiğinde üç öğretmen adayının da 
genel itibariyle planlarında yer verdikleri materyalleri derslerinde kullandıkları görülmüştür. Öğretmen adaylarının üçü de ortaokul matematik dersi öğretim programında yer alan kazanımların sırasını baz alarak derslerini hazırladıkları slaytlar aracılığıyla sürdürmüşlerdir. Slayt çalışmaları, öğretmenlerin ders içeriğini düzenli bir şekilde aktarmalarını sağlamaktadır (Akdağ ve Tok, 2004; Hlynka ve Mason, 1998). Öğretmen adaylarının deneyim eksiklikleri olduğu göz önüne alındığında hazırlamış oldukları sunumların dersin daha açık ve anlaşılır hale gelmesinde ve önemli noktaların atlanmadan verilebilmesinde önemli rol oynadığ çıkarımı yapılabilir. Sunumda kullanılan örnek soru ve açıklamalar için ders kitabından yararlanıldığ görülmüştür. Yusof ve Zakaria (2010) öğretmenlerin alan öğretme bilgilerini araştırdığ çalışmasında katılımcıların ders kitaplarında verilen içerikten oldukça sık yararlandıklarını belirtmiştir. Bunların yanında iki öğretmen adayı öğretim süreçlerinde kendilerinin hazırladıkları etkinlikleri kullanmışlardır. Hazırlanan etkinliklerin cebir öğrenme alanı kazanımlarına uygun olduğu görülmüştür. Öğretmen adayları ayrıca cebir öğrenme alanında yer alan konuların öğretimleri esnasında çeşitli matematik materyallerinden yararlanmışlardır.. Öğretmen adaylarının cebir öğrenme alanı kazanımları doğrultusunda cebir karoları, geometri tahtası ve terazi oluşturmak için askı materyallerinden yararlandıkları görülmüştür.

\section{5. Öneriler}

Çalışmadan elde edilen verilere göre, öğretmen adaylarının bilgi eksikliklerinin özellikle UAB bileşenlerinde yoğunlaştığ 1 görülmüştür. Öğretmen adaylarının öğrencilerin soru ve cevaplarını açıklayabilme, matematik alan dilini doğru bir şekilde kullanabilme, öğrencilere üretken matematik soruları yöneltebilme ve öğrenim sürecinde uygun değişiklikler yapabilme gibi becerilerinin yetersiz olması deneyim eksikliği ile ilişkili olabilir. Ancak, öğretmen adaylarının $\mathrm{UAB}$ bağlamındaki yetersizliklerinin ve buna etki eden öğrenim süreçlerindeki eksiklikler gibi faktörlerin daha kapsamlı olarak araştırılması gerekmektedir.

Araştırma sonuçları göz önünde bulundurulduğunda, öğretmenlerin temel cebir kavramları (değişken, bilinmeyen, eşitlik ve denklem) hakkında sınırlı alan bilgisine sahip oldukları ve bu yüzden kavramlar arasında anlamlı ilişkilendirmeler yapmakta sorun yaşadıkları görülmüştür. Bu sebeple, ilköğretim matematik öğretmenliği programında yer alan derslerde, öğretmen adaylarının temel cebir kavramlarının anlamlarını derinlemesine sorgulamalarını sağlayacak firsatlar sağlanmalıdır.

Çalışmada yer alan öğretmen adaylarının AÖB kapsamında öğrencilerin yaygın kavram yanılgıları ve hatalarına ilişkin sınırlı bilgiye sahip oldukları görülmüştür. Bu yüzden, öğretmen adayları cebir öğrenme alanına ilişkin öğretim gerçekleştirirken zaman zaman zorluk yaşamıştır. Tespit edilen zorluklar ve kavram yanılgıları senaryolaştırılarak öğretmen adaylarının lisans öğrenimleri sürecinde kullanılabilir. Bu şekilde, öğretmen adaylarının cebir öğrenme alanına ilişkin pedagojik alan bilgileri daha iyi düzeye getirilebilir.

Çalışmadan elde edilen bir diğer önemli sonuç da öğretmen adaylarının cebir öğrenme alanına ilişkin AÖtB'nde eksikliklerinin olmasıdır. Öğretmen adaylarının gerek hizmet öncesi (lisans dersleri) gerekse hizmet içi (öğretmen eğitimleri kapsamında seminer, kurs vb.) eğitimlerle, cebir öğretimini destekleyecek öğretim modelleri ve materyallerini hakkında bilgi sahibi olmaları sağlanmalıdır. Ayrıca, öğretmen adaylarının gerçek sınıf ortamlarında sıkça öğretim deneyimi yaşamalarının mümkün olmadığ çalışmalarından yararlanılarak öğretim süreçlerinin ÖMB modeline göre incelenmesi sağlanabilir. Öğretmen adaylarının öğretim süreçleri hakkında bilgi sahibi olmaları sonraki öğretim süreçlerini planlarken dikkat etmeleri gereken noktaları gözden kaçırmamaları açısından önemlidir.

Çalışmada, genel olarak öğretmen adaylarının öğretim süreçlerinde zorluk yaşadığı ve yanılgıya düştüğ̈̈ noktalar tespit edilmeye çalışılmıştır. Elde edilen verilerin öğretmen adaylarının yetiştirilmesi sürecinde kulanılması faydalı olabilir. Çalışmanın farklı üniversitelerde öğrenim gören öğretmen adaylarıyla da gerçekleştirilip sayıca genişletilmesi 
durumunda ortaokul matematik öğretmenlerinin cebir öğrenme alanına ilişkin bilgi düzeyleri daha detaylı olarak incelenebilir. Ayrıca, bu çalışma yine ÖMB kuramsal çerçevesi bağlamında farklı öğrenme alanlarına da uyarlanarak tekrarlanabilir. Bu sayede öğretmen adaylarının çeşitli öğrenme alanlarına ilişkin eksiklikleri tespit edilebilir ve bu eksikliklere ilişkin çözümler geliştirebilmek için firsatlar elde edilebilir.

\section{Etik Kurul Onay Bilgileri}

Araştırma ile ilgili İzmir Dokuz Eylül Üniversitesi, Eğitim Bilimleri Enstütüsü Müdürlüğü Etik Kurulu'nun 17/11/2014 tarihli oturumunda uygunluk onayı alınmıştır (Toplantı sayısı 13, Karar numarası 8).

\section{KAYNAKÇA}

Akar, G. K. (2010). Bir matematik öğretmeni ne bilmeli? Alan bilgisi ve alan eğitimi bilgisi arasındaki fark. Boğaziçi Üniversitesi Eğitim Dergisi, 27(2), 33-47.

Akdağ, H. ve Tok, H. (2004, Temmuz). Geleneksel öğretim ile powerpoint sunum destekli ögretimin öğrenci erişisine etkisi. XIII. Ulusal Eğitim Bilimleri Kurultayı'nda sunulmuş bildiri, Malatya.

Arslan, B. (2003). Bilgisayar destekli eğitime tabi tutulan ortaöğretim öğrencileriyle bu süreçte eğitici olarak rol alan öğretmenlerin BDE’ye ilişkin görüşleri. TOJET: The Turkish Online Journal of Educational Technology, 2(4), 67-75.

Aslan Tutak, F. (2009). A study of geometry content knowledge of elementary preservice teachers: The case of quadrilaterals. (Unpublished doctoral dissertation). University of Florida. Florida.

Aydın, A. (2007). Sınıf yönetimi. Ankara: Tek Ağaç Eylül Yayıncılık.

Ball, D. L. (1990). Breaking with experiences in learning to teach mathematics: The role of a preservice methods course. For the Learning of Mathematics, 10(2), 10- 16.

Ball, D. L., Hill, H. H., \& Bass, H. (2005). Knowing mathematics for teaching: Who knows mathematics well enough to teach third grade, and how can we decide? American Educator, 29(1), 14-46.

Ball, D. L., Lubienski, S. T., \& Mewborn, D. S. (2001). Research on teaching mathematics: The unsolved problem of teachers' mathematical knowledge. Handbook of Research on Teaching, 4, 433-456.

Ball, D. L., Thames, M. H., \& Phelps, G. (2008). Content knowledge for teaching: What makes it special? Journal of Teacher Education, 59(5), 389-407.

Baş, S., Çetinkaya, B. ve Erbaş, A. K. (2011). Öğretmenlerin dokuzuncu sınıf öğrencilerinin cebirsel düşünme yapılarıyla ilgili bilgileri. Eğitim ve Bilim, 36(159), 41-55.

Başer, N. ve Narlı, S. (2003). Matematik öğretmenlerinin öğretim yöntemlerini kullanmada karşılaştıkları sorunlar. Matematikçiler Derneği Bilim Köşesi.

Borko, H., Eisenhart, M., Brown, C. A., Underhill, R. G., Jones, D., \& Agard, P. C. (1992). Learning to teach hard mathematics: Do novice teachers and their instructors give up too easily?. Journal for Research in Mathematics Education, 23(3), 194-222.

Budak, İ., Budak, A., Tutak, T. ve Dane, A. (2009). Matematikte düz anlatım ve problem çözme sınıflarındaki öğretmen-öğrenci etkileşim farklılıklarının karşılaştırılması. Journal of Qafqaz University, 28(2), 180-189. 
Carpenter, S. R. (2003). Incorporation of a cooperative learning technique in organic chemistry. Journal of Chemical Education, 80, 330-332.

Çelik, D., Özmen, Z., Aydın, S., Güler, M., Birgin, O., Açıkııldız, G., ve diğerleri. (2018). İlköğretim matematik öğretmeni adaylarının matematik hakkındaki inançlarının ulusal düzeyde karş1laştırılması. Eğitim ve Bilim, 43(193), 289-315.

Dede, Y. ve Peker, M. (2007). Öğrencilerin cebire yönelik hata ve yanlış anlamaları: Matematik öğretmen adaylarının bunları tahmin becerileri ve çözüm önerileri. Illkögretim Online, 6(1), 35- 49.

Dede, Y., Yalın, H. ve Argün, Z. (2002, Eylül). Illköğretim 8.sınıf öğrencilerinin değissken kavramının ögrenimindeki hataları ve kavram yanılgıları. V. Ulusal Fen Bilimleri ve Matematik Eğitimi Kongresinde sunulan bildiri, Ankara.

Eisenhart, M., \& Borko, H. (1993). Designing classroom research: Themes, issues, and struggles. Allyn \& Bacon, A Division of Simon \& Schuster, Inc., 160 Gould Street, Needham Heights, MA 02194.

English, L. D., \& Halford, G. S. (1995). Mathematics education: Models and processes. Mahwah, NJ: Erlbaum.

Erbaş, A. K. ve Ersoy, Y. (2002). Dokuzuncu sınıf öğrencilerinin eşitliklerin çözümündeki başarıları ve olası kavram yanılgıları. UFBMEK-5 Bildiri Kitabı, 16-18.

Ersoy, Y. ve Ardahan, H. (2003). Illköğretim okullarında kesirlerin öğretimi $\quad$ II: $\quad$ Taniya yönelik etkinlikler düzenleme. Erişim adresi: http://www.matder.org.tr/bilim/ ioko2tyed.asp?ID=49, 27.04.2005

Ersoy, Y. ve Erbaş, A. K. (2005). Kassel projesi cebir testinde bir grup Türk öğrencinin genel başarıs1 ve öğrenme güçlükleri. Elementary Education Online, 4(1), 18-39.

Even, R., \& Tirosh, D. (1995). Subject-matter knowledge and knowledge about students as sources of teacher presentations of the subject-matter. Educational Studies in Mathematics, 29(1), 1-20.

Even, R., \& Markovits, Z. (1995). Some aspects of teachers' and students' views on student reasoning and knowledge construction. International Journal of Mathematical Education in Science and Technology, 26(4), 531-544.

Gage, N. L. \& Berliner, D. C. (1994). Educational psychology. Boston: Houghton Mifflin.

Garil, B., \& Silverman, F. (2009). Beyond the classroom walls: Helping teachers recognize mathematics outside of the school. Relime, 12(3), 333-354.

Gess Newsome, J. (1999). Pedagogical content knowledge: An introduction and orientation. In Examining pedagogical content knowledge (pp. 3-17). Springer, Dordrecht.

Ginsburg, H. P., \& Amit, M. (2008). What is teaching mathematics to young children? A theoretical perspective and case study. Journal of Applied Developmental Psychology, 29(4), 274-285.

Goulding, M., Rowland, T., \& Barber, P. (2002). Does it matter? Primary teacher trainees' subject knowledge in mathematics. British Educational Research Journal, 28(5), 689704.

Grouws, D. A., \& Schultz, K. A. (1996). J. Sikula (Ed.), In Handbook of research on teacher education. Macmillan Library Reference USA, Simon \& Schuster Macmillan, 1633 Broadway, New York, NY 10019.

Herscovics, N., \& Kieran, C. (1980). Constructing meaning for the concept of equation. The Mathematics Teacher, 73, 572-580. 
Hill, H. C. (2007). Mathematical knowledge of middle school teachers: Implications for the No Child Left Behind policy initiative. Educational Evaluation and Policy Analysis, 29(2), 95-114.

Hill, H. C., \& Ball, D. L. (2004). Learning mathematics for teaching: Results from California's mathematics professional development institutes. Journal for Research in Mathematics Education, 35(5), 330-351.

Hill, H. C., \& Lubienski, S. T. (2007). Teachers' mathematics knowledge for teaching and school context: A study of California teachers. Educational Policy, 21(5), 747-768.

Hlynka, D., \& Mason, R. (1998). Powerpoint in the classroom: Where is the power? Educational Technology, 38(5), 42-45.

Işık, A., \& Çelik, E. (2017). Effect on student achievement of teaching algebraic equations with worksheets. Kastamonu Eğitim Dergisi, 25(5), 1893-1908.

Işık, E. ve Çağdaşer, B. T. (2009). Yapısalcı yaklaşımla cebir öğretiminin 6. sınıf öğrencilerinin matematiğe yönelik tutumlarına etkisi. Kastamonu Üniversitesi Kastamonu Ĕ̈itim Dergisi, 17(3), 941-954.

İnan, C. (2006). Matematik öğretiminde materyal geliştirme ve kullanma. Dicle Üniversitesi Ziya Gökalp Ĕ̈itim Fakültesi Dergisi, 7, 47-56.

Jones, I., \& Pratt, D. (2006). Connecting the equals sign. International Journal of Computers for Mathematical Learning, 11(3), 301-325.

Kennedy, M. M. (1993). A Study Package for Examining and Tracking Changes in Teachers' Knowledge. NCRTL Technical Series, 93-1, 1-160.

Kieran, C. (1990). Cognitive processes involved in learning school algebra. In P. Nesher \& J. Kilpatrick (Ed.), Mathematics and Cognition (pp. 96-112). New York: Cambridge University Press.

Kolis, M., \& Dunlap, W. P. (2004). The knowledge of teaching: The K3P3 model. Reading Improvement, 41(2), 97-108.

Koşar, E., Yüksel, S., Özkılıç, R., Avc1, U., Alyas, Y. ve Çiğdem, H. (2003). Öğretim teknolojileri ve materyal geliştirme. Ankara: Pegem Akademi Yayınları.

MacGregor, M., \& Stacey, K. (1993). Cognitive models underlying students' formulation of simple linear equations. Journal for Research in Mathematics Education, 24, 217-232.

Maxwell, J. A. (1996). Qualitative research design. California: Sage Publication.

MEB. (2008). Öğretmen yeterlikleri: Öğretmenlik mesleği genel ve özel alan yeterlikleri. Ankara: Devlet Kitapları Müdürlüğü.

Merriam, S. B. (2013). Nitel arastirma: Desen ve uygulama icin bir rehber (Çev. Ed. Selahattin Turan). Ankara: Nobel Yayincilik.

National Council of Teachers of Mathematics [NCTM]. (2000). Principles and standards for school mathematics. Commission on Standards for School Mathematics, Reston, VA.

Olkun, S. ve Yeşildere, S. (2007). Sınıf öğretmeni adayları için temel matematik 1. Ankara: Maya Akademi.

Orton, A., \& Orton, J. (1999). Pattern and the approach to algebra. Pattern in the teaching and learning of mathematics, 104-120.

Özkan, H. H. (2011). Matematik dersinde öğretmenlerin ders içi yönelttiği sorular ve öğrenci cevapları düzeyi. Elektronik Sosyal Bilimler Dergisi, 35(35), 64-81. 
Özmantar, M. F. Bozkurt, A., Demir, S., Bingölbali, E. ve Açıl, E. (2010). Sınıf öğretmenlerinin etkinlik kavramına ilişkin algıları. Selçuk Üniversitesi Ahmet Keleşoğlu Eğitim Fakültesi Dergisi, 30, 379-398.

Öztürk, İ. H. (2012). Öğretimin planlanmasında öğretmenin rolü ve özerkliği: Ortaöğretim tarih öğretmenlerinin yıllık plan hazırlama ve uygulama örneği. Kuram ve Uygulamada Eğitim Bilimleri, 12, 271-299.

Raymond, A. M. (1997). Inconsistency between a beginning elementary school teacher's mathematics beliefs and teaching practice. Journal for Research in Mathematics Education, 28(5), 550-576.

Russell, S. J. (1999) Mathematical reasoning in the elementary grades. In Lee V. Stiff (Ed.), Developing mathematical reasoning in grades K-12 / 1999 yearbook. Reston, Virginia: National Council of Teachers of Mathematics.

Ryan, J., \& McCrae, B. (2006). Assessing pre-service teachers' mathematics subject knowledge. Mathematics Teacher Education and Development, 7, 72-89.

Shulman, L. S. (1987). Knowlegde and teaching: Foundations of the new reform. Harvard Educational Review, 57(1), 61-77.

Shulman, L. S. (1986). Those who understand: Knowledge growth in teaching. Educational Researcher, 15(2), 4-14.

Tabuk, M. (2003). İlköğretim 7. sinfflarda “çember, daire ve silindir” konusunun öğretiminde bilgisayar destekli ögretimin başarlya etkisi. (Yayınlanmamış Yüksek Lisans Tezi). Marmara Üniversitesi Eğitim Bilimleri Enstitüsü. İstanbul.

Tanışl1, D. ve Yavuzsoy Köse, N. (2010, Mayıs). Sınıf öğretmeni adaylarının örüntüleri genellemeleri: Görsel stratejilerin etkisi. 9. Ulusal Sınlf Öğretmenliği Ë̆itimi Sетровуити, 220-225, Elazı̆̆.

Teachervision. (2010). Levels of questions in Bloom's Taxonomy. Retrieved from http://www.teachervision.fen.com/teaching-methods/new-teacher/48445.html

Tirosh, D. (2000). Enhancing prospective teachers"e knowledge of children"es conceptions: The case of division of fractions. Journal for Research in Mathematics Education, 31(1), 525.

Toluk Uçar, T. (2011). Öğretmen adaylarının pedagojik içerik bilgisi: Öğretimsel açıklamalar. Türk Bilgisayar ve Matematik Eğitimi Dergisi, 2(2), 87-102.

Ubuz, B., Erbas, A. K, Çetinkaya, B. ve Özgeldi, M. (2010). Exploring the quality of the mathematical tasks in the new Turkish elementary school mathematics curriculum guidebook: the case of algebra. ZDM Mathematics Education, 42, 483-491.

Uğurel, I. ve Bukova Güzel, E. (2010). Matematiksel öğrenme etkinlikleri üzerine bir tartışma ve kavramsal bir çerçeve önerisi. Hacettepe Üniversitesi Eğitim Fakültesi Dergisi, 39, 333-347.

Van den Kieboom, L. A. (2013). Examining the mathematical knowledge for teaching involved in pre-service teachers' reflections. Teaching and Teacher Education, 35, 146-156.

Warren, E., \& Cooper, T. (2008). Generalising the pattern rule for visual growth patterns: Actions that support 8 year olds' thinking. Educational Studies in Mathematics, 67(2), 171-185.

Yaman, H. (2010). İlköğretim öğrencilerinin matematiksel örüntülerdeki ilişkileri algılayışları üzerine bir inceleme. (Doktora Tezi). Hacettepe Üniversitesi Sosyal Bilimler Enstitüsü. Ankara. 
Yeşildere, S. (2007). İlköğretim matematik öğretmen adaylarının matematiksel alan dilini kullanma yeterlikleri. Boğaziçi Üniversitesi Ĕ̌itim Dergisi, 24(2), 61-70.

Yeşildere, S., \& Akkoç, H. (2010). Algebraic generalization strategies of number patterns used by preservice elementary mathematics teachers. Procedia Social and Behavioral Sciences, 2, 1142-1147.

Yıldırım, A. ve Şimşek, H. (2008). Sosyal bilimlerde nitel araştırma (6. Baskı). Ankara: Seçkin Yayınları.

Yusof, Y. M., \& Zakaria, E. (2010). Investigating secondary mathematics teachers pedagogical content knowledge: A case study. Journal of Education and Sociology, 1(1), 32-39.

\section{EKLER}

\section{Ek 1. Bileşenlere İlişkin Görüşme Formu}

Sayın Hocam,

$\mathrm{Bu}$ görüşmede amacım, 8.sınıf cebir öğrenme alanına ilişkin öğretim süreçleri hakkındaki düşüncelerinizi daha detaylı öğrenebilmektir. Bu amaçla öncelikle size bazı matematik soruları soracağım, sonrasında bu tür soruları öğrencilerinizin anlayabilmesi için ne tür yöntemler uyguladığınızı yani onları nasıl anlaşılabilir kıldığınızı öğrenmek için size bazı sorular yönelteceğim. Görüşme sonucunda topladığım bilgileri araştırma raporumda kullanacağım, ancak görüşmenin gizliliği için isminiz kesinlikle rapora yansıtılmayacak, isminiz şifrelenerek kullanılacaktır. Bununla birlikte, görüşme sürecinde söylediklerinizin hiç birini kaçırmamak için ses kayıt cihazı kullanacağım ve görüşme sırasında söylediklerinizi hatırlayabilmeme yardımcı olacak notlar alacağım. İzninizle, görüşmemize başlayabiliriz.

\section{A. Genel Alan Bilgisi}

1. Özdeşlik ve denklem arasındaki fark nedir?

2. Kenar uzunluğu 1 birim olan 50 adet altıgenin bir kenarları ortak olacak şekilde yan yana dizilmesiyle elde edilen şeklin çevre uzunluğu ne olur?

3. Ela, kardeşinin tam olarak iki katı yaştadır. Bir daha bu durum ne zaman gerçekleşir?

\section{B. Uzmanlık Alan Bilgisi}

1. Farz edelim ki öğrencilerinize birinci dereceden bir bilinmeyenli denklemleri öğretiyorsunuz. Örneğin; $x+7=12$

$\mathrm{Bu}$ soruyu çözmeye nereden başlarsınız? Bunu öğretmenin en iyi yolu sizce nedir? Öğrenciler yaptığınız açıklamayı anlamazsa bu soruyu açıklayabilecek alternatif bir yol var midir?

2. Öğrencileriniz standart olmayan bir yolla soruyu çözerse ona nasıl bir açıklama yaparsiniz?

3. Soruları standart olmayan yaklaşımlarla çözmeleri için teşvik eder misiniz? Neden?

4. Özdeşlik kavramının açıklanabilmesi için birden fazla yönteminiz var mı? Eğer varsa sizce hangisi standart yoldur?

5. Değişken kavramını öğretmeye başladığınızda en sık hangi zorluklarla karşılaşıyorsunuz? Bu zorluğu ortadan kaldırmak için etkili bir yönteminiz var $\mathrm{m} 1$ ? 


\section{Alan ve Öğrenci Bilgisi}

1. Denklemlerin öğretiminde formal stratejiler ile informal stratejileri nasıl bir araya getirirsiniz?

2. Denklemleri öğretme sürecinizde öğrencilerinizin yaptığı hatalar nelerdir? Öğrenci niçin bu tür hataları yapıyor olabilir? Hatalar nasıl düzeltilebilir?

3. Öğrencilerin cebir konularına ilişkin kavram yanılgıları ve yaygın hatalarına ilişkin yeterliliğiniz ile ilgili kendinizi nasıl görüyorsunuz?

4. Sizce 8. sınıf cebir öğrenme alanındaki hangi konuları öğrencilerin anlaması daha uzun zaman alır?

\section{Alan ve Öğretme Bilgisi}

1. Cebir konularını ele aldığınız bir derste hangi etkinlik ve materyalleri kullanmayı tercih edersiniz? Neden?

2. Cebir öğretiminde sizce en etkili öğretimsel strateji nedir? Açıklayınız.

3. Cebir konularını işlediğiniz bir derste, öğrencilerinizin derse daha iyi motive olabilmeleri için sınıfınızda nasıl düzenlemeler yaparsınız?

\section{Ek 2. Gözlem Formu}

Öğretmen :

Okulu :

Gözlemci :

Sinifi :

Konu :

Öğrenci Sayısı :

$(E)=$ Eksiği var $(\mathrm{K})=$ Kabul edilebilir $(\mathrm{I})$ = İyi Uygun olan seçeneği $(+)$ ile işaretleyiniz.

\begin{tabular}{|c|c|c|c|c|c|c|}
\hline & & & $\mathrm{E}$ & $\mathrm{K}$ & $\dot{\mathrm{I}}$ & Yorumlar \\
\hline $\mathbf{1 . 0}$ & \multicolumn{5}{|c|}{ ALAN BİLGISİ } & \\
\hline 1.1 & \multicolumn{5}{|c|}{ Genel Alan Bilgisi } & \\
\hline & 1.1 .1 & Problemleri doğru bir şekilde çözebilme & & & & \\
\hline & 1.1 .2 & Öğrencilerin hatalarını farkedebilme & & & & \\
\hline & 1.1.3 & $\begin{array}{l}\text { Konuya ait terimleri ve notasyonları doğru bir şekilde } \\
\text { kullanabilme }\end{array}$ & & & & \\
\hline \multirow[t]{5}{*}{1.2} & \multicolumn{5}{|c|}{ Uzmanlık Alan Bilgisi } & \\
\hline & 1.2 .1 & Öğrencilerin sorularını nedenleriyle birlikte açıklayabilme & & & & \\
\hline & 1.2 .3 & Matematik alan dilini doğru bir şekilde kullanabilme & & & & \\
\hline & 1.2 .4 & Kazanımlara ulaştıcı nitelikte soru sorabilme & & & & \\
\hline & 1.2 .5 & Öğretim sürecinde değişiklik yapabilme & & & & \\
\hline 2.0 & \multicolumn{5}{|c|}{ PEDAGOJİK ALAN BİLGISİ } & \\
\hline \multirow[t]{4}{*}{2.1} & \multicolumn{5}{|c|}{ Alan ve Öğrenci Bilgisi } & \\
\hline & 2.1 .1 & $\begin{array}{l}\text { Öğrencilerin yaygın hatalarının ve kavram yanılgılarının } \\
\text { engelleyici yaklaşımlarda bulunmak }\end{array}$ & & & & \\
\hline & 2.1 .2 & Öğrencilerin zorlanacakları noktaları tahmin edebilme & & & & \\
\hline & 2.1 .3 & $\begin{array}{l}\text { Öğrencilere ilginç gelebilecek, motive edici etkinliklerden } \\
\text { derslerinde yararlanabilme }\end{array}$ & & & & \\
\hline
\end{tabular}




\begin{tabular}{|l|l|l|l|l|l|}
\hline 2.2. & \multicolumn{3}{|l|}{ Alan ve Öğretme Bilgisi } & \multicolumn{2}{|l|}{} \\
\hline & 2.2 .1 & $\begin{array}{l}\text { Ders planına uygun bir şekilde öğretim sürecine devam } \\
\text { etme }\end{array}$ & & & \\
\hline & 2.2 .2 & Uygun strateji, yöntem ve tekniklerden yararlanabilme & & & \\
\hline & 2.2 .3 & $\begin{array}{l}\text { Ders materyallerini dersin amacı doğrultusunda } \\
\text { kullanabilme }\end{array}$ & & & \\
\hline
\end{tabular}

\section{Ek 3. Derslere Yönelik Genel Görüşme Formu}

Sayın Hocam,

Bugün gerçekleştireceğimiz görüşmede, 8.sınıf cebir öğrenme alanına ilişkin işlediğiniz ders üzerine size bazı sorular yönelteceğim. Bu görüşmede amacım, ders süreciniz ile ilgili genel düşüncelerinizi öğrenmektir. $\mathrm{Bu}$ görüşmeyle birlikte işlediğiniz derse ilişkin daha detaylı bilgilere ulaşacağımı düşünüyorum. Görüşme sürecinde söylediklerinizi kaydedeceğim. Kayıtların tümü gizlidir. Araştırma sonuçlarını yazarken, görüştügümm bireylerin isimlerini kesinlikle rapora yansıtmayacağım. İzninizle, görüşmeye başlayabiliriz.

1. Ders işleme sürecinizde izlenmek size nasıl hissettirdi?

2. İzleniyor olmanız, öğretim sürecinizde herhangi bir değişiklik yapmanıza neden oldu mu? Eğer olduysa açıklar mısınız?

3. Dersinizden önce yapmayı planladıklarınızla öğretim sürecinde gerçekleşen durumları karşılaştırır mısınız?

4. Sizi özellikle memnun eden durumlar oldu mu? Niçin?

5. Sizi hayal kırıklığına uğratan herhangi bir olay yaşandı mı? Niçin?

6. Kendi öğretim sürecinizi (videonuzu) izlerken nasıl hissettiniz?

7. Anlattı̆̆ınız konular öğrencilerinizin ilgisini çekebildi mi? Siz bu konuda neler yaptınız?

8. Öğretim sürecinizde kullandığınız örnekler ve açıklamalar için hangi kaynaklardan yararlandınız?

9. Kullandığınız etkinlikleri ve ders materyallerini seçme sebebiniz neydi?

10. Kullandığınız etkinliklerin ve ders materyallerinin avantajları ve dezavantajları var mıydı? Açıklar mısınız?

11. Matematik dersinizi planlarken öğretim programından yararlandınız mı? Eğer yararlandıysanız, nasıl yararlandığınızı açıklar mısınız?

12. Öğrencilerinizin bireysel farklılıklarından, günlük yaşam deneyimlerinden öğretim sürecinizde yararlandınız mı? Açıklar mısınız?

\section{EXTENDED ABSTRACT}

\section{Introduction}

The purpose of this study is to examine the elementary school mathematics teacher candidates' subject matter knowledge and pedagogical content knowledge regarding the 8th grade algebra learning field by using Mathematical Knowledge for Teaching (MKT) model which developed by Ball, Thames and Phelps (2008). MKT model reveals the knowledge that teachers should have for teaching mathematics. It is thought that this model can be used as a guide in mathematics teaching and thus contribute to the teacher training process. 


\section{Method}

The research was conducted by using the case study design, which is one of the qualitative research methods. The participants of the study were three middle school mathematics teacher candidates who were in their last year of the learning process in a state university in Turkey. The teacher candidates who took part in the study were determined by criterion sampling method. First of all, interviews were made with each teacher candidate regarding the components of the MKT model. Then, the teaching processes of the teacher candidates were observed and recorded with a video camera. After the teaching processes were completed, another general interview was held with the teacher candidates.

The interviews conducted with the teacher candidates, video recordings of the lessons and observation notes constitute the data source of the study. In this respect, various data collection tools were developed being "Interview Form Regarding Components", "Lesson Observation Form" and "General Interview Form for the Lessons".

\section{Results and Discussion}

The study results indicated that there are deficiencies in "Subject Matter Knowledge" and "Pedagogical Content Knowledge" of the teacher candidates regarding the algebra learning field. It was determined that the shortcomings of the teacher candidates were mainly in the "Specialized Content Knowledge" components. In this context, teacher candidates were found to be insufficient in explaining students' questions and answers, using the mathematics field language correctly, directing productive mathematics questions to students and making appropriate changes in the learning process. This important results may be related to the lack of professional experience of teacher candidates. However, the factors affecting this situation, such as deficiencies in education and training processes, need to be investigated more comprehensively.

During the research process, it was observed that teacher candidates had limited "Common Content Knowledge" about basic algebra concepts (variable, unknown, equality and equation) and therefore had difficulty in establishing connections between concepts. For this reason, opportunities should be provided for teacher candidates in the middle school mathematics teacher education program to gain a deep understanding of basic algebra concepts.

It was observed that the teacher candidates in the study had limited knowledge about the common misconceptions and mistakes of students within the scope of "Knowledge of Content and Students". Therefore, teacher candidates sometimes had difficulties in the teaching processes of the algebra learning area. The identified difficulties and misconceptions can be used in the undergraduate education process of teacher candidates by creating scenarios. In this way, teacher candidates' Pedagogical Content Knowledge on algebra learning field can be improved.

Another important result obtained from the study is that teacher candidates have deficiencies in "Knowledge of Content and Teaching" related to the field of learning algebra. It should be ensured that teacher candidates learn teaching models, materials and tools that will make algebra teaching meaningful and provide rich learning opportunities through both undergraduate courses and additional seminars and courses. In addition, in cases where it is not possible for teacher candidates to have frequent teaching experience in real classroom environments, micro-teaching studies can be used to examine the teaching processes according to the MKT model. These activities are important for teacher candidates to be familiar with the points they should consider when planning their teaching processes.

In the study, the points where teacher candidates generally have difficulties and make mistakes in their teaching processes have been investigated. It may be useful to use the data obtained at the end of the research in the process of training teacher candidates. By conducting the study with teacher candidates from different centers, the knowledge levels of middle school 
mathematics teachers about the field of learning algebra can be examined in more detail. In addition, this study can also be carried out by adapting it to different learning areas in the context of the MKT theoretical framework. In this way, the shortcomings of teacher candidates regarding various learning areas can be identified and opportunities can be obtained to develop solutions for these deficiencies.

\section{Conclusions}

The study results indicated that the mathematical knowledge of the teacher candidates was not adequate for providing effective instruction and their shortcomings are mainly related to the insufficiency of the components of the specialized content knowledge. Factors affecting this important situation should be investigated in detail. 